
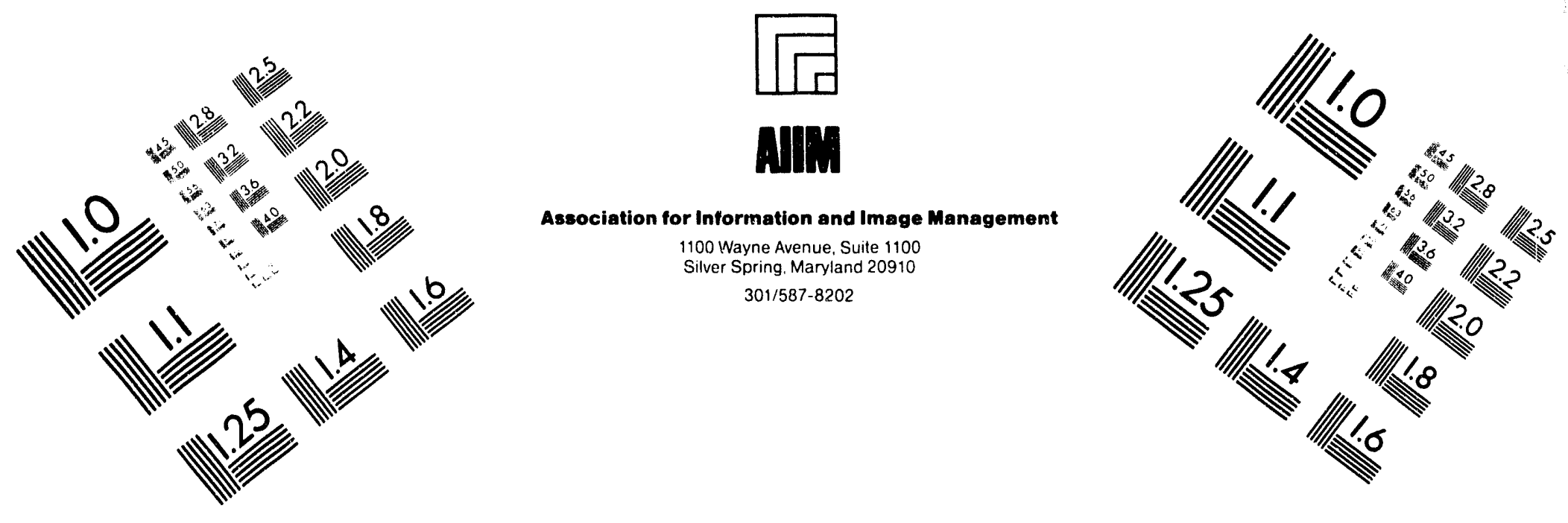

Centimeter

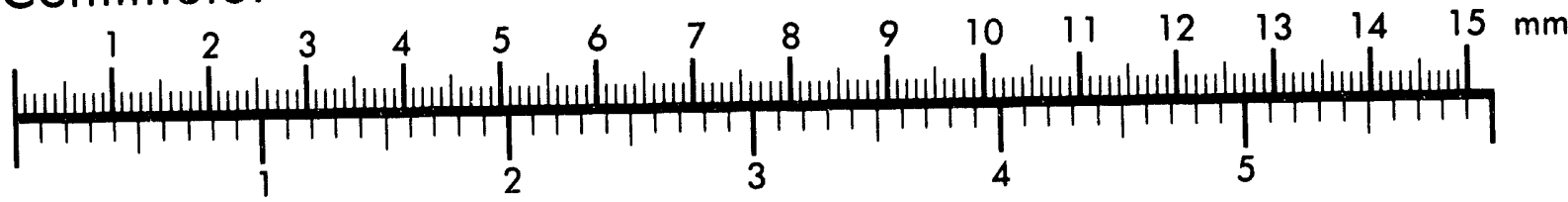
Inches
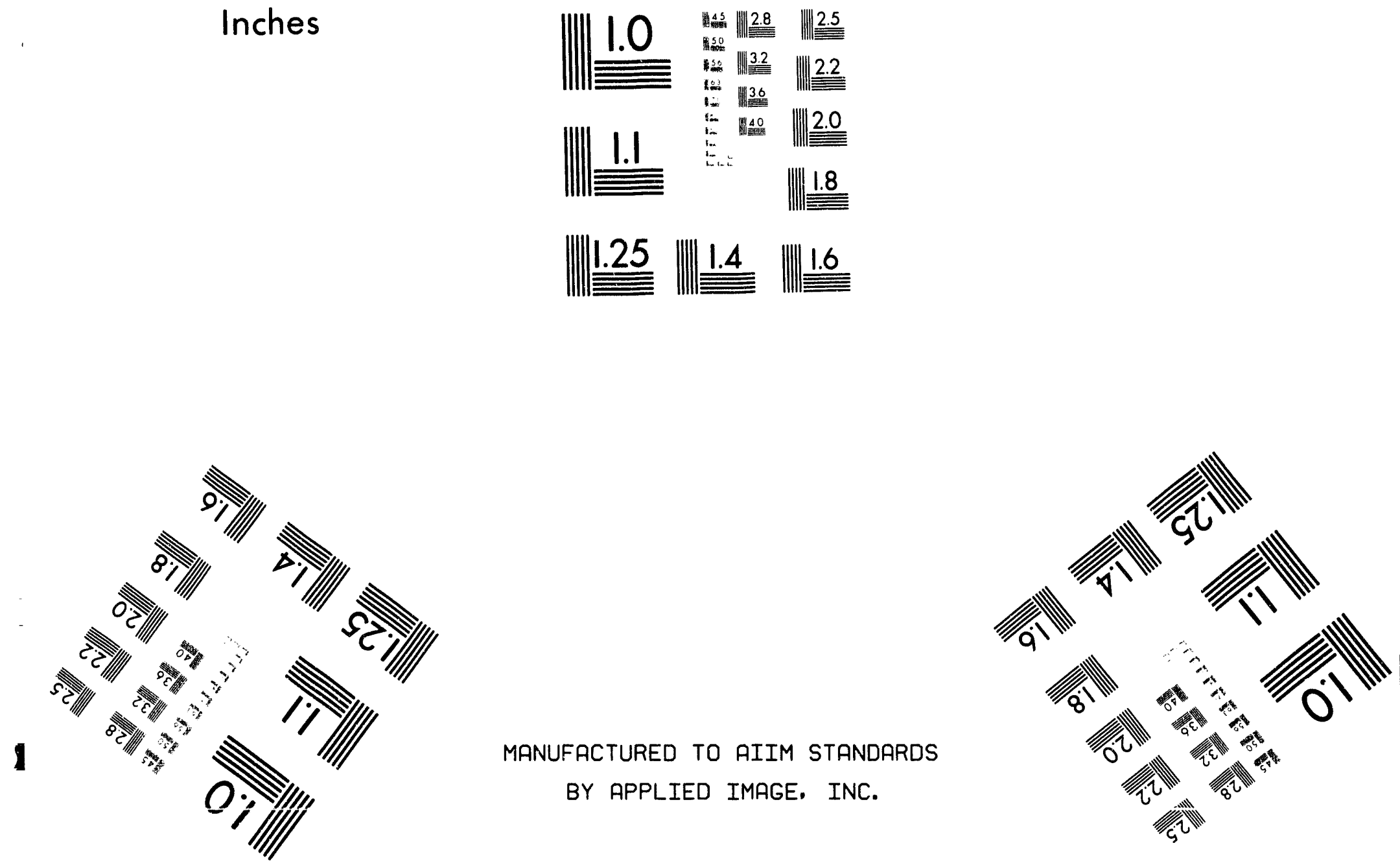

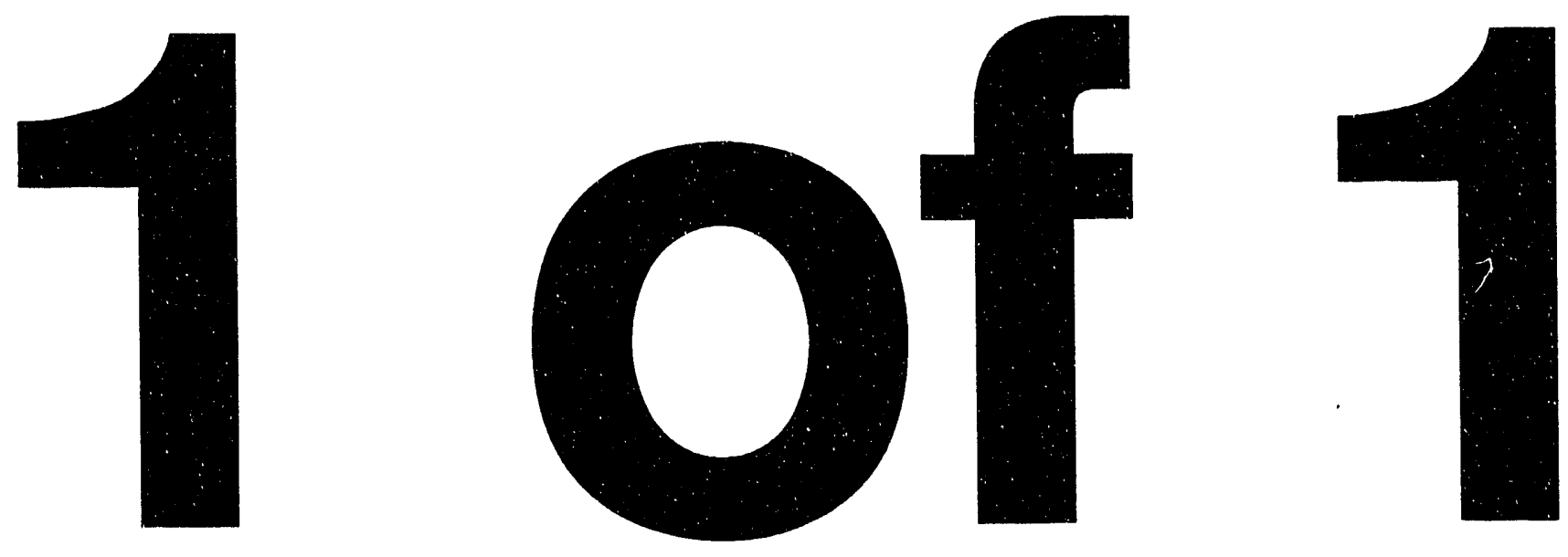
PNL -8715

UC -350

\title{
RESULTS FROM AN \\ ENERGY-EFFICIENT \\ SHOWERHEAD FIELD STUDY
}

\begin{abstract}
W. M. Warwick
S. A. Bailey
\end{abstract}

June 1993

Prepared for

the Bonneville Power Administration

under a Related Services Agreement

with the U.S. Department of Energy

Contract Number DE-ACO6-76RLO 1830

Pacific Northwest Laboratory

Richland, Washington 99352

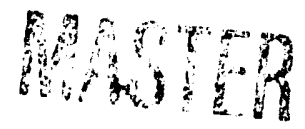




\section{ABSTRACT}

In 1991 the Bonneville Power Administration (Bonneville) initiated research to determine the energy savings potential of energy-efficient showerheads, including a two-phase study by Pacific Northwest Laboratory (PNL). The

PNL study focused on 154 homes monitored with end-use metering equipment. In the first phase of the study, PNL recruited participants from the homes, installed energy efficient showerheads, and collected occupant and site characteristics data. The second phase of the study is an analysis of the end-use load data to estimate energy use and savings from showerheads over a two-year period. This report presents the results from the first phase field study.

Program results are based on the number of homes that participated in various aspects of the study. Among the 154 of homes selected for the study, 65\% agreed to participate. Eighty-eight percent of these homes actually had their showerheads replaced. After 15 months, $94 \%$ of the homes where showerheads were installed still had at least one in place.

Measure results are based on the number of showerheads that were installed. The 154 homes contained an estimated 240 showerheads that could have been replaced. Sixty-six percent of these showerheads were actually replaced. If only showers in participant homes are considered, $83 \%$ of the showerheads were replaced. Measure persistence at the end of 15 months was $94 \%$.

The water flow rate from existing showerheads averaged 3.2 gallons per minute (gpm) at participating sites. Average water pressure for city-supplied water was 66 pounds per square inch (psi). Water pressure at homes on wells was over $40 \%$ lower, which reduced savings potential. The energy-efficient showerheads had an average flow rate of $1.8 \mathrm{gpm}$. Observed water flow reductions of $1.4 \mathrm{gpm}$ were obtained from retrofit of energy-efficient showerheads. In about $20 \%$ of the showers, water flows remained constant or actually increased after retrofit of energy-efficient showerheads. 
SUMMARY

The Bonneville Power Administration (Bonneville) initiated research to determine the energy saving potential of energy-efficient showerheads. The research was implemented in several phases by the Pacific Northwest Laboratory (PNL). The first phase was a field study designed to identify field conditions associated with the installation of, and potential savings from, energy-efficient showerheads. Bonneville collected energy use data from field study participants concurrent with this field study to use in the second phase of energy savings analysis. This report is limited to the first phase field study.

A total of 150 single-family Regional End-Use Metering Program (REMP) sites were eligible for participation in this study (out of 154 in REMP). The sites are located in Oregon, Washington, Idaho, and Western Montana, and, although probably not statistically representative of the region, they include a cross section of residences and occupants. To recruit field-study participants, residents were offered a $\$ 40$ cash incentive, free showerheads, free professional installation, and a return of their old showerheads upon request.

Savings from energy-efficient showerheads depend on several program factors, including participation in a retrofit program, replacement of highflow showerheads with energy-efficient showerheads, and use of the retrofit showerheads for bathing. Savings are dependent on field conditions, such as existing water flow rates, water pressure, and type of water system. A summary of field study results on these topics is provided below.

\section{PROGRAM AND MEASURE RESULTS}

The savings from retrofit programs depend on both participation in the program and installation of measures. Many homes have more than one shower. Consequently, results need to distinguish between number of homes in the program and number of showerheads. 


\section{PROGRAM FACTORS}

Program participation rate is the number of showerheads distributed to the program participants. Of the 150 sites eligible to participate in this study, 111 elected to participate. However seven withdrew, for a total of 105 who participated in the site visit. Six homes dropped out during the site visits, resulting in a $65 \%$ program participation rate. Program participation factors are further explained in Table S.1.

Program penetration is defined as the fraction of participants who actually had showerheads installed. Ninety-eight of the initial 111 households who volunteered to participate were retrofit with energy-efficient showerheads for an $88 \%$ program participation rate.

Program persistence is based on the fraction of the households that installed showerheads where at least one showerhead remained in service. After 15 months, 92 of the 98 homes that were retrofitted retained at least one showerhead for a $94 \%$ program persistence rate.

Measure participation is based on the actual number of showerheads distributed compared to the total number that could be installed. In this study it is estimated that the original 150 potential participants had 240 showerheads. Of the 240, 158 were replaced for an approximate measure participation of $66 \%$.

Measure penetration is based on the number of efficient showerheads installed compared to the number that could have been installed. Of the total 161 showerheads in the 98 participant homes, 158 showerheads were replaced for a measure penetration of $98 \%$ for the 98 homes and $66 \%$ for the 150 original eligible homes.

Measure persistence is based on the fraction of measures that remian in service compared to the number installed. Of the 158 showerheads that were installed in the 98 homes, 149 remained in service after 15 months for a $94 \%$ measure persistence rate. 
IABLE S.1. Program Participation History

\begin{tabular}{|c|c|c|}
\hline $\begin{array}{l}\text { REMP residential } \\
\text { program sites }\end{array}$ & 154 & \\
\hline $\begin{array}{l}\text { REMP'91 Survey } \\
\text { respondent sites }\end{array}$ & 143 & $\begin{array}{l}154 \text { were surveyed by mail, } 143 \text { were } \\
\text { returned (The REMP' } 91 \text { is separate from } \\
\text { the field study described in this report; } \\
\text { however the same sites were used so data } \\
\text { from REMP ' } 91 \text { are used for some } \\
\text { comparisons in this report.) }\end{array}$ \\
\hline $\begin{array}{l}\text { REMP Showerhead Program } \\
\text { Original Sample }\end{array}$ & 150 & $\begin{array}{l}4 \text { of the } 154 \text { REMP sites were not eligible } \\
\text { for program participation because they } \\
\text { were manufactured homes or were known to } \\
\text { have a gas water heater }\end{array}$ \\
\hline \multirow[t]{2}{*}{$\begin{array}{l}\text { REMP showerhead sites } \\
\text { recruited }\end{array}$} & 111 & $\begin{array}{l}111 \text { of the } 150 \text { agreed initially to } \\
\text { participate }\end{array}$ \\
\hline & -6 & $\begin{array}{l}6 \text { of the } 111 \text { homes were dropped from the } \\
\text { study before the site visits--either the } \\
\text { owner changed mind or we learned the home } \\
\text { had a gas water heater }\end{array}$ \\
\hline \multirow{2}{*}{$\begin{array}{l}\text { REMP initial shower } \\
\text { participants (homes } \\
\text { visited) }\end{array}$} & 105 & 105 sites were visited \\
\hline & -7 & $\begin{array}{l}\text { At } 7 \text { homes the owners changed their minds } \\
\text { about participating or we decided not to } \\
\text { install a new showerhead because we found } \\
\text { nonstandard plumbing or a gas water heater }\end{array}$ \\
\hline \multirow[t]{2}{*}{$\begin{array}{l}\text { REMP showerhead final } \\
\text { participants }\end{array}$} & $98^{(a)}$ & $\begin{array}{l}\text { New showerheads were actually installed in } \\
98 \text { sites }\end{array}$ \\
\hline & -7 & $\begin{array}{l}3 \text { had missing data and } 4 \text { had gas water } \\
\text { heaters }\end{array}$ \\
\hline $\begin{array}{l}\text { REMP energy-savings } \\
\text { showerhead sites }\end{array}$ & $91^{(b)}$ & 91 sites had complete sets of useable data \\
\hline \multicolumn{3}{|c|}{$\begin{array}{l}\text { (a) Participation, penetration and persistence calculations are based on } \\
\text { the } 98 \text { sample size. } \\
\text { (b) All energy-savings calculations are based on the sample size of } 91 \text {. }\end{array}$} \\
\hline
\end{tabular}




\section{FIELD CONDITIONS}

Energy savings from retrofit showerheads result from reduced hot water use. This field study measured actual water flow rates to assess energy savings potential. Energy-efficient showerheads rated at $2.5 \mathrm{gpm}$ (brandname Ondine) and $2.0 \mathrm{gpm}$ (brandname ETL) were retrofit in this study. Flow rates and changes are provided in Table S.2.

Energy-efficient showerheads effectively reduced water flows. However, the average $44 \%$ flow rate reduction masked a wide variation that included flow increases at $15 \%$ of the ETL sites and $23 \%$ of the Ondine sites. Low water pressure was associated with these sites ( $<1.34 \mathrm{gpm})$.

Twenty percent of the participants had wells. The average water pressure for well-supplied homes was 37.9 pounds per square inch (psi), as compared to 66.1 psi for city-supplied homes.

TABLE S.2. Average Water Flow Results (in gpm)

\begin{tabular}{|l|c|c|c|c|c|c|}
\hline & $\begin{array}{c}\text { Number of } \\
\text { Showerheads }\end{array}$ & Rating & $\begin{array}{c}\text { Pre- } \\
\text { Flow }\end{array}$ & $\begin{array}{c}\text { Post- } \\
\text { Flow }\end{array}$ & Change & $\%$ \\
\hline ETL Sites & 136 & 2.0 & 3.09 & 1.67 & 1.42 & -46 \\
\hline Ondine Sites & 22 & 2.5 & 3.89 & 2.55 & 1.34 & -34 \\
\hline Overal1 & 158 & NA & 3.21 & NA & 1.41 & -44 \\
\hline (a) for 98 sites where showerheads were retrofit. \\
\hline
\end{tabular}

Showering frequency is another key factor in showerhead savings. Survey responses indicate showering is the major form of bathing with $69 \%$ of the showers being used "frequently" (at least four times weekly). In sites that had 2 showers, $71 \%$ of those replaced were said to be used frequently. In sites that had 3 showers, $52 \%$ of those replaced were said to be used frequently.

\section{MAJOR CONCLUSIONS}

These specific field study results are not significantly different from results reported elsewhere in the Pacific Northwest. However, showerhead 
savings potential appears to be less than initial expectations--especially the finding that pre-retrofit flow rates are close to $3 \mathrm{gpm}$ rather than $5 \mathrm{gpm}$ and that roughly $20 \%$ of retrofit showerheads actually show increased flows.

Further, this study used a very aggressive design yet managed to convert twothirds of the potential showerheads instead of the 85-90\% expected. The cumulative effect of lower-than-expected flow reductions and retrofit rates is savings that are 65-70\% less than the anticipated $2.5-\mathrm{gpm}$ flow reductions and 85-90\% retrofit rates intially expected.

This field study is based on a relatively small sample of single-family homes. Results from this study are not necessarily representative of the Pacific Northwest region or other types of residences. Nevertheless, this research is the most comprehensive undertaken in the region to date, and represents the best source of information for Bonneville's program planning and evaluation. 


\section{ACKNOWLEDGMENTS}

The study designers would like to thank Curtis Hickman of the Bonneville Power Administration for his guidance and support. We would like to express our appreciation to Pacific Science and Technology who conducted the site visits. We would like to acknowledge the contribution of James Bavry, formerly of the Pacific Northwest Laboratory, for his data analysis efforts. We would also like to acknowledge the following PNL staff members for their efforts in conducting the study and preparing this report: Annet Dittmer, Gordon Haber, Anita Lauhala, Jan Schwab, Linda Seidel, and Terri Gilbride. 


\section{CONTENTS}

SUMMARY

1.0 INTRODUCTION . . . . . . . . . . . . . . . . . . . . 1.1

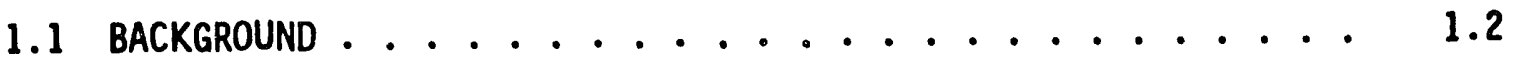

1.2 OVERVIEW OF THE REPORT . . . . . . . . . . . . 1.2

2.0 FIELD PROCEDURES . . . . . . . . . . . . . . . . . . . 2.1

2.1 RECRUITMENT . . . . . . . . . . . . . . . 2.1

2.2 INSTALLATION AND CHARACTERISTICS DATA COLLECTION . . . . . 2.2

2.3 FLOW DATA MEASUREMENTS . . . . . . . . . . . . . 2.4

2.4 RETROFIT SHOWERHEAD CHOICE . . . . . . . . . . . . 2.5

3.0 RESULTS . . . . . . . . . . . . . . . . . . . 3.1

3.1 SHOWER CHARACTERISTICS . . . . . . . . . . . . . 3.1

3.1.1 Number of Showers . . . . . . . . . . 3.2

3.1.2 Reasons for Nonreplacement . . . . . . . . . 3.2

3.1.3 Water Pressure and Flow Rates . . . . . . . . 3.5

3.2 OCCUPANT CHARACTERISTICS . . . . . . . . . . . . 3.12

3.2.1 Profile of Site Occupants . . . . . . . . . 3.12

3.2.2 Frequency of Showering and Other Hot-Water Usages , 3.14

3.3 SITE CHARACTERISTICS . . . . . . . . . . . . . 3.15

3.3.1 Participants' Water Heaters . . . . . . . . 3.16

3.3.2 Non-Shower Hot-Water Using Devices . . . . . . . 3.20

4.0 POST-INSTALLATION TELEPHONE SURVEY . . . . . . . . . . . . . . 4.1

4.1 POST-INSTALLATION TELEPHONE SURVEY METHOD . . . . . . . . 4.1

4.2 PARTICIPANT SATISFACTION WITH SHOWERHEADS . . . . . . . 4.2

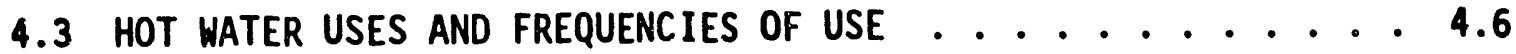

4.4 MISCELLANEOUS RESPONSES . . . . . . . . . . . . . 4.7 


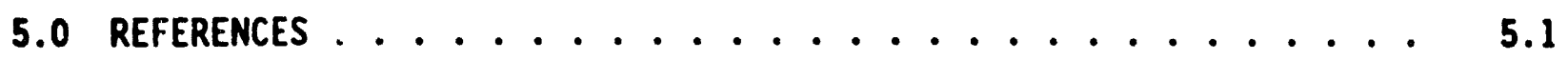

APPENDIX A - SHOWERHEAD RETROFIT INSTALLATION REPORT . . . . . A A.l

APPENDIX B - SHOWERHEAD INSTALLATION CHECKLIST . . . . . . . B. B.

APPENDIX C - PARTICIPATION AGREEMENT AND CERTIFICATE OF PARTICIPATION C.1

APPENDIX D - TELEPHONE SURVEY ................ D.1 


\section{FIGURES}

3.1 Pre-flow Rate versus Pressure . . . . . . . . . . . 3.6

3.2 Post-Flow Rate versus Pressure . . . . . . . . . . . 3.6

3.3 Distribution of Measured Pre-Flow Rates . . . . . . . . . 3.9

\section{İ̈BLES}

1.1 Previous Bonneville Residential Energy Use Studies . . . . . 1.3

1.2 Current Showerhead Field Studies . . . . . . . . . . . 1.3

2.1 Sample Disposition ........................ 2.3

3.1 Household shower Characteristics . . . . . . . . . . 3.3

3.2 Installations .................... . . . . . . . .

3.3 Reasons for Nonreplacement of Showerheads . . . . . . . . . 3.4

3.4 Water Pressure and Pre- and Post-Installation Flow Rate Descriptive Statistics for ETL Spa 2001 Showerhead Installations $\mathbf{3 . 7}$

3.5 Water Pressure and Pre- and Post-Installation Flow Rate Descriptive Statistics for Ondine Showerhead Installations . . . 3.7

3.6 Pearson and Spearman Correlation Coefficients for Pressure, Flows, and Change in Flow for ETL Spa 2001 Showerhead Installations . .

3.7 Pearson and Spearman Correlation Coefficients for Pressure, Flows, and Change in Flow for Ondine Showerhead Installations .....

3.8 Showerhead Savings Estimates at Various Retrofit Flow Rates . . 3.10

3.9 Water Pressure and Flow Rates for the Total Sample and by Low, Medium, and High Water Pressure Groupings........... . 3.11

3.10 Water Pressure for Sites With and Without a Well . . . . . . 3.11

3.11 Number of Occupants per Site . . . . . . . . . . . 3.13

3.12 Comparison of Participants and Non-Participants in Terms of Their 1991 and 1992 Survey Mean Number of Persons by Age Category . . .

3.13 Shower Usage . . . . . . . . . . . . . . . . 3.15 
3.14 Household Showers and Other Hot Water Uses per Week . . . . . 3.16

3.15 Comparison of Participant and Nonparticipant Data on Water Heaters..........................

3.16 Water Heater Fuel by Type of Area Served . . . . . . . . . . . 3.18

3.17 Water Heater Descriptive Data for 95 Electric Water Heaters at 91 Participating Sites ....................

3.18 Use of Hot Water Booster with Non-Shower Hot Water Using Devices

4.1 Means and Standard Deviations for Five Showerhead Satisfaction Items ..............................

4.2 Response Frequencies for a Variety of Telephone Survey Items . • 4.4

4.3 Valid Number of Responses, Means and Standard Deviations for Items Measuring Shower and Water Usage ............. 4.6

4.4 Number and Percent by Frequency of Running Out of Hot Water . . . 4.8

4.5 Number and Percent by Source of Water . . . . . . . . . . . 4.8 


\subsection{INTRODUCTION}

Bonneville initiated the Energy-Efficient Showerhead Field Data Collection Project in August 1991. The goal of the project is to collect site-specific field data regarding the installation of energy-efficient showerheads. The field data collection effort was implemented by the Pacific Northwest Laboratory (PNL) to collect information about site and occupant characteristics that may affect participation in energy-efficient showerhead programs and performance of energy-efficient showerheads in use. In the course of the field study, data was collected on the following:

- installation of showerheads

- site and occupant characteristics

- post-installation retention and satisfaction.

The procedures used to recruit and install energy-efficient showerheads mirrored those encountered in a showerhead retrofit program: customers were solicited to participate, arrangements were made to install showerheads, and payments were made after installation. As a result, observations were made that permitted identification of, and inferences about, program implementation barriers, installation problems, and measure penetration rates.

This report summarizes data from the showerhead field study and appropriate data from a 1991 survey of 154 homes participating in Bonneville's Regional End-Use Metering Program (REMP). Results are also given for a follow-up telephone survey of project participants performed in 1992, approximately eight months after the showerhead installations, as part of the showerhead field study.

At the outset of this field study, it was anticipated by Bonneville and PNL that the data collected during this field study would be analyzed by PNL and form one portion of the larger program evaluation. Subsequently, PNL was awarded a contract for data analysis, as well as related contracts for the process evaluation of the water heating efficiency program and the impact evaluation of water usage measures (i.e., energy-efficient showerheads and faucet aerators). This report presents only the results of the field study. Energy savings and program impacts will be covered in other reports. 


\subsection{BACKGROUND}

The field study was conducted among participants in Bonneville's Regional End-Use Metering Program (REMP) to decrease the expense and time associated with energy-use data collection. The REMP sites are descendants of earlier Bonneville residential energy-use research.

In 1983, Bonneville conducted a regional residential survey of over 4,000 residences in the Northwest, called the Pacific Northwest Residential Energy Consumption Survey (PNWRES). A sample of these residences was recruited for inclusion in the End-Use Load and Conservation Assessment Project (ELCAP), a multi-year study Bonneville initiated in 1985. Under ELCAP, energy-use monitoriny equipment was installed to individually meter a variety of electrical circuits in over 400 selected buildings. ELCAP's successor is the Regional Energy Metering Program (REMP), which continues data collection from a sub-set of the original ELCAP sites. A total of 158 singlefamily homes are still participating in the REMP metering study. Of these 158 sites, 150 were eligible for the showerhead installation field study described in this report. (Some were ineligible because they had gas water heaters.) This lineage provides a wealth of survey and energy use data. A summary of selected Bonneville residential energy use data and studies are presented in Table 1.1.

\subsection{OVERVIEW OF THE REPORT}

This report contains five chapters. Chapter 1 provides an introduction to the research and an orientation to the report. Field procedures are described in Chapter 2. Results are presented in Chapter 3. Chapter 4 discusses conclusions of the study and their limitations. The references are in Chapter 5. Appendix A contains a copy of the field survey instrument. Appendix $B$ contains field data collection protocols. Appendix $C$ contains a copy of the participation agreement and the certificate issued to occupants of visited sites. Appendix $D$ contains the telephone survey instrument used to assess customer use of, and satisfaction with, the energy-efficient showerheads. 
IABLE 1.1. Previous Bonneville Residential Energy Use Studies

\begin{tabular}{|c|c|c|}
\hline $\begin{array}{l}\text { Year of } \\
\text { Survey }\end{array}$ & Title of Study & Purpose and Scope \\
\hline 1983 & $\begin{array}{l}\text { Pacific Northwest } \\
\text { Residential Energy } \\
\text { Consumption } \\
\text { Survey (PNWRES) }\end{array}$ & $\begin{array}{l}\text { A survey of } 4,700 \text { single-family residences in the Northwest to } \\
\text { record energy use and occupant characieristics }\end{array}$ \\
\hline $\begin{array}{l}1985 \\
1990\end{array}$ & $\begin{array}{l}\text { End-Use Load } \\
\text { Assessment and } \\
\text { Consumer } \\
\text { Program (ELCAP) }\end{array}$ & $\begin{array}{l}\text { Install data loggers to meter electrical energy end-uses within } \\
\text { homes and commercial buildings to determine energy use } \\
\text { patterns for hours of the day, days of the week, and weeks of } \\
\text { the year. Data loggers were initially installed in } 440 \text { single- } \\
\text { family residences, } 48 \text { multi-family residences, and } 144 \\
\text { commercial buildings. }\end{array}$ \\
\hline $\begin{array}{l}1990 \text { to } \\
\text { present }\end{array}$ & $\begin{array}{l}\text { Regional End-Use } \\
\text { Metering Project } \\
\text { (REMP) }\end{array}$ & $\begin{array}{l}\text { The ELCAP energy end-use metering program included } 251 \\
\text { single-family residences, } 7 \text { multi-family residences, and } 102 \\
\text { commercial buildings as of Oct. 1, 1990. REMP is a } \\
\text { continuation of this metering program with only selected sites. } \\
\text { By } 1991,154 \text { single-family homes remained in the study. }\end{array}$ \\
\hline 1991 & $\begin{array}{l}1991 \text { REMP } \\
\text { Survey }\end{array}$ & $\begin{array}{l}\text { A survey of REMP single-family homes to collect data on } \\
\text { occupants and household characteristics. } 143 \text { of the } 154 \text { sites } \\
\text { still in REMP participated in this survey. }\end{array}$ \\
\hline
\end{tabular}

IABLE 1.2. Current Showerhead Field Studies

\begin{tabular}{|l|l|l|}
\hline $\begin{array}{l}\text { Year of } \\
\text { Survey }\end{array}$ & Title of Study & Purpose and Scope \\
\hline $1991-$ & $\begin{array}{l}\text { Showerhead } \\
\text { Installation } \\
\text { Study }\end{array}$ & $\begin{array}{l}\text { Installed energy-efficient showerheads in 98 REMP residences } \\
\text { to collect data to compare to previous energy use studies to } \\
\text { help determine energy savings from installation of this measure. } \\
\text { Original participant pool was 150 of the 154 REMP sites. Of } \\
\text { these, 105 were visited and showerheads were installed at 98 } \\
\text { sites. }\end{array}$ \\
\hline 1992 & $\begin{array}{l}\text { Showerhead } \\
\text { Study - Follow- } \\
\text { up Telephone } \\
\text { Survey }\end{array}$ & $\begin{array}{l}\text { A follow-up survey that questioned participants of the } \\
\text { showerhead installation field study on their attitudes toward, } \\
\text { and use of, the energy-efficient showerheads installed in their } \\
\text { homes. }\end{array}$ \\
\hline 1993 & $\begin{array}{l}\text { Showering } \\
\text { Behavior Survey }\end{array}$ & $\begin{array}{l}\text { Received } 85 \text { responses from 154 REMP sites that were } \\
\text { surveyed by mail about household showering and other hot } \\
\text { water uses. }\end{array}$ \\
\hline
\end{tabular}




\subsection{EIELD PROCEDURES}

This field study included several specific activities:

- recruitment of participants

- site characterization

- initial occupant survey

- showerhead installation (retrofit)

- follow-up satisfaction survey.

The first section describes the recruitment of sites for particination in the showerhead installation field study. This is followed by sectiois describing the collection of site characteristics data and showerhead flow data at each site. The last section in this chapter describes the selection of showerhead brands for use in this study. Survey information was primarily used to analyze field observations and is presented in Chapter 3.

\subsection{RECRUITMENT}

Ali single-family homes in the REMP metering program were eligible for participation in the showerhead field study except for homes with gas water heaters. A total of 150 sites were eligible for participation in the study. These sites are located in Bonneville's service area in Washington, Oregon, Idaho, and western Montana.

The REMP participants are accustomed to research requests and are normally very cooperative. The recruitment process included telephone solicitations which offered the following:

- a $\$ 40$ cash incentive

- no-cost replacement of existing showerheads with energy-efficient models

- return of the original showerheads at any time.

In addition, consumers were informed in advance that the retrofit would be conducted by a professional installer and that any minor plumbing problems that prevented proper operation of the retrofit showerhead would be repaired. This customer-oriented offer was designed to ensure a high participation rate 
due to the limited number of potential participants and the desire for a final sample of approximately 100 sites. Of the 150 eligible sites, 111 volunteered to participate, or $74 \%$.

A certain amount of attrition is expected in any voluntary study. This study was no exception. Of the 111 recruited sites, 6 dropped out during the initial site inspection stage. During the site inspection, 7 more sites were dropped from the study. Consequently, 98, or 65\%, of the eligible population participated in the study. From another perspective, we actually installed energy-efficient showerheads in 98 of the 111 participant sites for an $88 \%$ participant rate. The disposition of potential participants, and the reasons for sampie attrition are shown in Table 2.1. As noted, the savings calculations are based on complete data sets from the 91 "net" participants, excluding 4 sites with gas water heaters and 3 sites with insufficient data.

\subsection{INSTALLATION AND CHARACTERISTICS DATA COLIECTION}

Shortly after recruitment, each site was visited by trained installation personnel. The following activities were conducted during this visit:

- Confirm participant interest.

- Verify site characteristics (from ELCAP/REMP records) and update these records.

- Collect neces'ary occupant survey data.

- Locate, identify, and inspect each bathroom and note which had showers.

- Collect showerhead flow rate information.

- Replace showerhead (if desired by participant).

- Collect post-retrofit flow rate data.

After the site visit was completed, the participants received the $\$ 40$ cash incentive and a certificate of participation (shown in Appendix $\mathrm{C}$ ). At that time, participants were asked to sign a participation agreement (also shown in Appendix $C$ ) and reminded that they could request return of their old showerheads anytime during the next year. The old showerheads were tagged and stored so they could be returned if requested. Installations began in August 1991 and continued through November 1991. 
IABLE 2.1. Sample Disposition

\begin{tabular}{|c|c|c|c|}
\hline & & \multicolumn{2}{|c|}{ Households } \\
\hline \multicolumn{2}{|c|}{ Potential population } & & 150 \\
\hline \multicolumn{2}{|c|}{ Volunteers } & & 111 \\
\hline \multicolumn{4}{|c|}{ Drop-outs } \\
\hline \multicolumn{2}{|r|}{ EESH in place } & 2 & \\
\hline \multicolumn{2}{|r|}{ Changed mind } & 2 & \\
\hline \multicolumn{2}{|r|}{ Aesthetics } & 1 & \\
\hline \multicolumn{2}{|c|}{ Vacant } & 1 & \\
\hline \multicolumn{2}{|r|}{ Drop-out Total } & 6 & \\
\hline \multicolumn{2}{|c|}{ Sites Visited } & & 105 \\
\hline \multicolumn{4}{|c|}{ Drop-outs } \\
\hline \multicolumn{2}{|r|}{ EESH in place } & 1 & \\
\hline \multicolumn{2}{|r|}{ Changed mind } & 1 & \\
\hline \multicolumn{2}{|r|}{ Non-electric water heater } & 2 & \\
\hline \multicolumn{2}{|r|}{ Non-standard plumbing } & 2 & \\
\hline \multicolumn{2}{|r|}{ Drop-out Total } & 7 & \\
\hline \multicolumn{2}{|c|}{ Participating sites } & & $98^{(\mathrm{a})}$ \\
\hline \multicolumn{4}{|c|}{$\begin{array}{l}\text { (a) Seven of these were not used in most analyses - four were sites } \\
\text { with gas water heaters that were inadvertently retrofitted and } \\
\text { three others had missing data - so net participating sites was } \\
91 \text {. } \\
\text { EESH = energy-efficient showerhead }\end{array}$} \\
\hline
\end{tabular}

The installers collected information on a variety of site and occupant characteristics as indicated on the Showerhead Retrofit Installation Report (see Appendix $A$ ). Field personnel were guided in their work by a Showerhead Installation Checklist (see Appendix B). The following characteristics information was collected for each participating home:

- site identification number, equipment control number, date of installation, and installer identification 
- water heater size, age, model number, fuel type, location characteristics, insulation of tank or pipes, presence of heat trap, and zone served for each water heater in the home

- number and type of hot water-using devices at each site

- location (e.g., master bath) and type (shower only, tub/shower combination, etc.) of all showers in the home

- type of valve fixtures (tub/shower valve, diverter spout, single valve mixer, separate hot and cold valves, etc.) in each shower

- frequency of use of each of the showers

- whether the showerhead was replaced

- household water pressure

- water flow rates (gpm) at "bath" temperature

- light fixture location, bulb type, number of bulbs, and number of bulbs missing or burned out (This data was collected for use in a supplementary study.)

Written comments from the installer about the visit were also included in the installation report.

\subsection{FLOW DATA MEASUREMENTS}

Installers measured water flow before and after showerhead replacement using a Micro Wier (Manclark 1991). In some cases, it was necessary to correct problems with the household plumbing prior to installation of the showerhead. Flow measurements were taken to reflect the effect of these changes, if any, as well. Flow measurements were at full flow, in the following sequence:

- before retrofit, flow through showerhead

- after showerhead retrofit, flow through showerhead

- after showerhead retrofit, flow through showerhead after diverter spout replacement or alteration, if any.

Showers can be activated through individual hot and cold water valves, mixing valves that combine hot and cold water, and diverter valves that cause a mix of hot and cold water to flow into the shower instead of into a bath 
tub. At times, diverter valves may not seal completely, allowing some water to continue to flow through the tub spout. Accordingly, the diverter spouts were examined during this field study. In cases where the diverter valves were ineffective, they were replaced and new flow measurements were taken.

Energy end-use data collection at the participating homes has been, and will continue, as an on-going activity through REMP. This includes collection of energy use information on an hourly basis for each household water heater, space heater, and total electricity use, as well as for each major appliance at most sites. One full year of energy end-use data will be used for analysis of showerhead energy savings.

\subsection{RETROFIT SHOWERHEAD CHOICE}

The performance of each brand of showerhead is different, al though several brands are included in the Bonneville program. The initial field study design specified a single brand and model of showerhead to reduce differences in estimated energy use from variations from one brand to another. However, two brands of showerheads were ultimately used as replacements. Both were chosen on the basis of previous program experience and cusiomer studies (Katzev 1991). The models selected are used extensively in the Pacific Northwest under utility showerhead retrofit programs.

The first choice was an Ondine brand showerhead. The Ondine model selected had a 2.5 gallon per minute (gpm) design flow rate. Bonneville staff indicated that this flow rate was approximately one-half of the average flow rate for installed showerheads ( 4 to $5 \mathrm{gpm}$ ). However, after completing installations in 13 homes (22 showerheads), field personnel noted lower-thanexpected flow rates before replacement. "Before" flow rates averaged $3.9 \mathrm{gpm}$ instead of between 4 and $5 \mathrm{gpm}$. A flow reduction from $3.9 \mathrm{gpm}$ to $2.5 \mathrm{gpm}$ (1.4 gpm) through installation of the Ondine showerheads was thought to be too small a change to measure using total water heating energy data for a sample of roughly 100 homes.

A second retrofit showerhead, the ETL Spa 2001 brand, (rated at $2.0 \mathrm{gpm}$ ) was purchased for use in the study, rather than discontinuing the study and leaving the question of showerhead savings unanswered. The remainder of the 
retrofits were completed with this showerhead. In total, 22 of the Ondine showerheads were installed in 13 homes. The remaining 85 homes had 136 of the Spa 2001 showerheads installed. Pre- and post-retrofit flow rates and other site measurement resuits appear in the next chapter. 


\subsection{RESULTS}

This section presents the data collected during the showerhead installation field study. The data collected cover three major areas: 1) shower characteristics, 2) occupant characteristics, and 3) site characteristics. In some instances, site and occupani characteristics data collected during the 1991 REMP survey are also presented. (The 1991 REMP survey was administered to each of the 154 REMP sites.) Data will be presented on each of these subjects.

Both the number of showers per site and the number of occupants per site vary. As a result, benchmarks used to present results will also vary depending on the subject. For example, the objective of this study was to collect information about potential electric water heating savings from showers. A total of 105 sites were visited and 98 sites had energy-efficient showerheads installed. Of these 98 sites, four used non-electric (gas) water heaters for heating bathing water. The purpose of this study was to collect data on electric water heating use characteristics, so these sites have been deleted from the remaining analyses. Similarly, three additional sites had incomplete site or characteristics data and could not be used for analysis.

As a consequence, the following savings analyses are based on data from the 91 remaining sites. These sites all meet the following criteria: have electric water heaters, had one or more showerheads replaced, and had water pressure and pre- and post-installation flow data available. These 91 sites are referred to as the "participants" in the tables and text. Sites not satisfying the criteria given were classified as non-participants.

\subsection{SHOWER CHARACTERISTICS}

Each of the 105 recruited sites was inspected to note the presence of showering facilities and their type. This included the collection of information on the bath tub-shower combinations and the types of valves used to activate the shower. This data was collected to identify factors that could affect the effectiveness of a showerhead retrofit program.

Specifically, the bath tub in a combination bath tub-shower may be used for bathing instead of the shower. In addition to this data, the resident was 
asked several questions about the use of showering facilities at the sites. Shower characteristics results are presented in Table 3.1.

\subsubsection{Number of Showers}

A total of 173 showers were found at the initial 105 sites, for an average of 1.65 showers per house. This is comparable to the mean number of showers per site (1.7) for homes that had participated in the 1991 REMP survey but did not participate in the showerhead installation study. The number of showers at each site varied from 1 to 3 , as follows:

- 47 sites had 1 shower each $=47$ showers

- 48 sites had 2 showers each $=96$ showers

- 10 sites had 3 showers each $=30$ showers

$$
\text { Total }=173 \text { showers at } 105 \text { sites }
$$

A total of 173 showers were candidates for showerhead replacement (see Table 3.2); 158 of these were replaced for a measure penetration rate of $91 \%$. Usable data was collected on 139 out of the 158 showerheads. The 91 homes accounted for 139 showerheads. Replacements were not made for 15 of the 173 showers for a variety of reasons (described in Section 3.1.2).

of the 105 sites, only 91 will be used for energy savings analyses due to non-electric water heaters and critical missing data. of these 91 sites, 139 showerheads were installed as follows:

- 48 sites received 1 showerhead (one site had one showerhead installed but other data is missing) $\quad 48$ heads

- 35 sites received 2 showerheads (four more of these sites had missing data) $=70$ heads

- 7 sites received 3 showerheads. $\quad 21$ heads

Total = 139 showerhead installations with useable data

\subsubsection{Reasons for Nonreplacement}

A total of 15 showerheads, or 9.5\%, were not replaced with energyefficient showerheads at the 105 sites for a variety of reasons. These reasons are listed in Table 3.3. One reason cited for not replacing a 


\section{IABLE 3.1. Household Shower Characteristics}

\begin{tabular}{|c|c|c|}
\hline & Number of Showers & Percent of Showers \\
\hline \multicolumn{3}{|l|}{ Showerhead replaced? } \\
\hline No & 15 & $9 \%$ \\
\hline Yes & 158 & $91 \%$ \\
\hline Missing data & 0 & $\therefore$ \\
\hline \multicolumn{3}{|l|}{ Type of showernath } \\
\hline Tub/shower & 108 & $63 \%$ \\
\hline Strower only & 62 & $36 \%$ \\
\hline Other & 1 & $1 \%$ \\
\hline Missing data. & 2 & - \\
\hline \multicolumn{3}{|l|}{ Diverter spout present? } \\
\hline No & 60. & $36 \%$ \\
\hline Yes & 105 & $64 \%$ \\
\hline Missing data & 8 & - \\
\hline \multicolumn{3}{|l|}{ Frequency of use } \\
\hline Frequently & 121 & $75 \%$ \\
\hline Infrequently & 46 & $28 \%$ \\
\hline Missing data & 6 & - \\
\hline \multicolumn{3}{|l|}{ Shower value type } \\
\hline Single & 137 & $80 \%$ \\
\hline Separate valves & 34 & $20 \%$ \\
\hline Missiny data & 2 & - \\
\hline \multicolumn{3}{|l|}{ Diverter velive replaced? } \\
\hline No & 107 & $97 \%$ \\
\hline Yes & $3^{(a !}$ & $3 \%$ \\
\hline Not applicable & 60 & - \\
\hline Missinp data & 3 & - \\
\hline \multicolumn{3}{|c|}{ Diverter valve repaired/altered? } \\
\hline No & 109 & $99 \%$ \\
\hline Yes & 1 & $1 \%$ \\
\hline Not applicatie & 59 & - \\
\hline Missing data & 4 & - \\
\hline \multicolumn{3}{|l|}{ Old showerhead efficient? } \\
\hline No & 41 & $40 \%$ \\
\hline Yes & 26 & $25 \%$ \\
\hline Unsure & 36 & $35 \%$ \\
\hline Missing data & 70 & - \\
\hline
\end{tabular}


IABLE 3.2. Installations (105 sites)

\begin{tabular}{|c|c|c|c|c|c|c|}
\hline $\begin{array}{c}\text { Number } \\
\text { of } \\
\text { Showers }\end{array}$ & $\begin{array}{c}\text { Number of } \\
\text { Sites }\end{array}$ & \multicolumn{4}{|c|}{$\begin{array}{c}\text { Number of Sites with This } \\
\text { Number of Showerheads Replaced }\end{array}$} & $\begin{array}{c}\text { Total Number } \\
\text { of Showerheads } \\
\text { Repl aced }\end{array}$ \\
\cline { 3 - 6 } & & 1 & 2 & 3 & 0 & \\
\hline 1 & 47 & 44 & NA & NA & 3 & 44 \\
\hline 2 & 48 & 3 & 43 & NA & 2 & 89 \\
\hline 3 & 10 & 1 & 0 & 8 & 1 & 25 \\
\hline Total: & 105 sites & \multicolumn{7}{|c|}{} & & 158 \\
\hline
\end{tabular}

showerhead was the owners' request; for example, in some cases the owner currently had a hand-held showerhead installed and did not want to lose the ability to use the shower as a hand-held device. Minor plumbing problems were corrected whenever possible to ensure a maximum number of showerhead replacements in the study. Nevertheless, plumbing problems prevented installation of four showerheads, or 2.3\%. A total of 14 showerlieads were retrofitted after potential installation barriers were overcome. These barriers (11 non-standard shower arms and 3 leaky diverter valves) were overcome through use of professional installation staff. These types of problems could present addition barriers in a program that relied on occupantinstallation of showerheads. If these 14 showerheaus are included in the "non-replacement" totals, 29 , or $17 \%$ of the potential showerheads, would fall into that category.

TABLE 3.3. Reasons for Nonreplacement of Showerheads (in 105 sites)

\begin{tabular}{|c|r|}
\hline Reason & Showerheads \\
\hline EESH in place & 1 \\
\hline Owners' request/changed mind & 3 \\
\hline Non-electric water heater & 2 \\
\hline Non-standard plumbing & 4 \\
\hline Missing & 5 \\
\hline Total & 15 \\
\hline
\end{tabular}


A total of 108 showers were in tub/shower combinations. Virtually all of these (105 showers) used a diverter in the tub spout to activate the shower. Three diverter spouts required replacement to ensure effective shower operation.

\subsubsection{Water Pressure and Flow Rates}

Water pressure and water flow rates are assumed to be primary determinants of showerhead flow rates. This study found a moderate correlation between water pressure and flow rates (see Figures 3.1 and 3.2). However, the difference in pre- and post-flow rate was highly correlated to the pre-flow rate. In other words, higher pre-flows resulted in a greater reduction after the efficient showerheads were installed, as expected. Again, water pressure was only moderately correlated with decrease in flow. As can be seen in Tables 3.4 and 3.5 , the variability of the flows was noticeably reduced by the retrofit installations. Tables 3.6 and 3.7 show Pearson and Spearman correlation coefficients for pressure, flows, and change in flow.

There was no change in flow rate or an increase in flow rate for $23 \%$ (5 of 22) of the Ondine showerheads installed and 13\% (18 of 136) of the Spa showerheads installed. This unexpected increase in flow rate may result from old showerheads that were clogged with corrosion or particles that had severely impeded water flow.

A bar graph and table illustrate the distribution of pre-flow rates for the 170 showers where pre-flow rates were measured (Figure 3.3). The table at the bottom of the bar chart provides a basis for estimating potential savings from showerhead retrofits with different flow rates. For example, 81 showerheads had rates of flow of greater than $3.0 \mathrm{gpm}$; reduced flows would be realized if these showerheads are replaced by showerheads rated at $3.0 \mathrm{gpm}$. A showerhead that is rated at $2 \mathrm{gpm}$ will result in reduced flows for a total of 121 showerheads, or 29\%. In other words the potential for savings varies as a function of the flow rate of the retrofit showerhead; the lower the flow rate, the greater the savings potential (see Table 3.8). 
Pre-Flow Rate Vs. Pressure

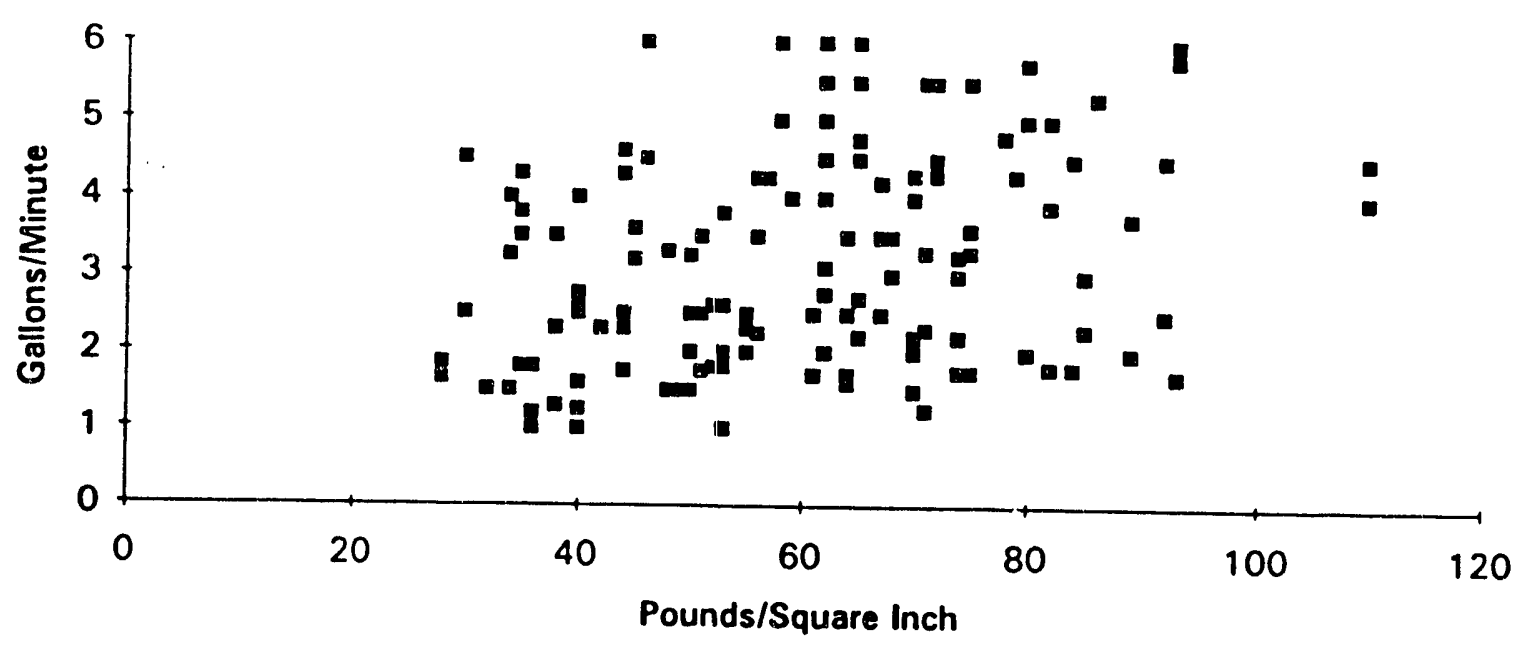

EIGURE 3.1. Pre-Flow Rate versus Pressure

Post-Flow Rate Vs. Pressure

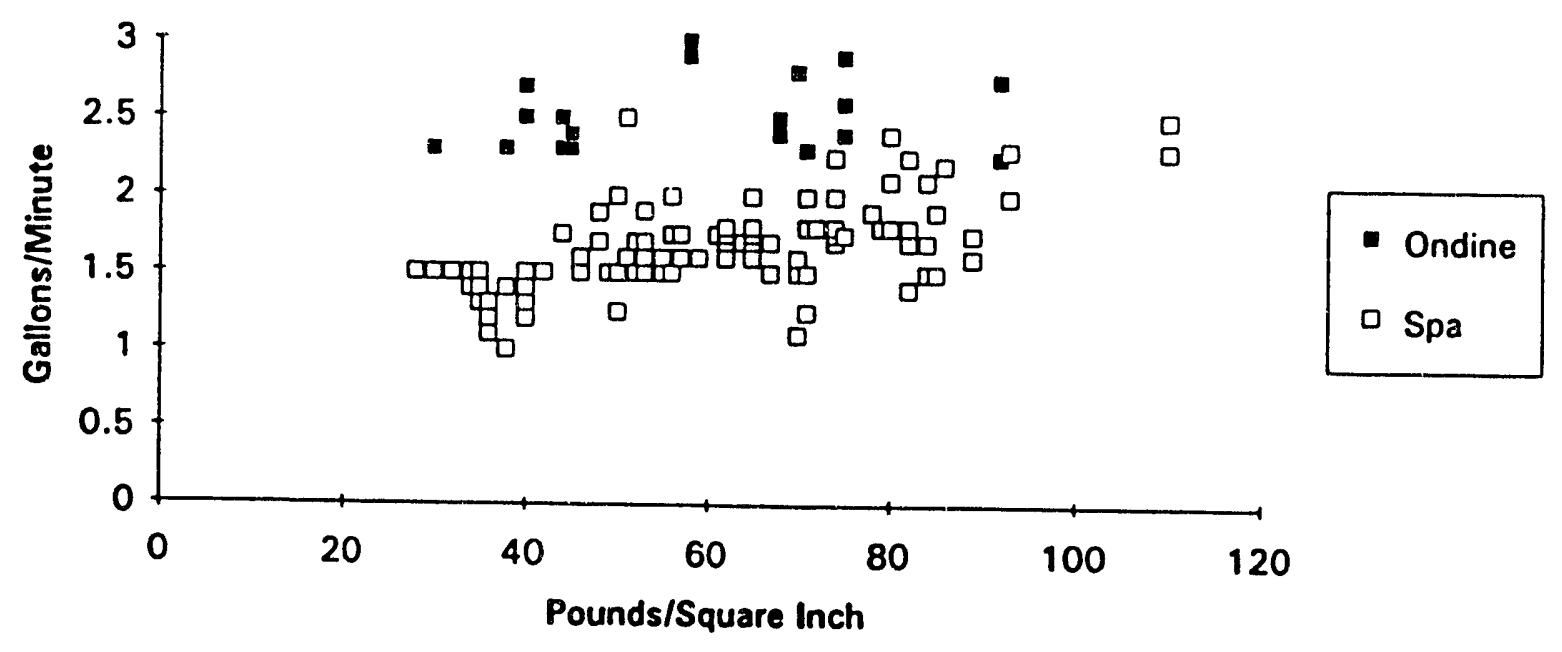

EIGURE 3.2. Post-flow Rate versus Pressure 
IABLE 3.4. Water Pressure and Pre- and Post-Installation Flow Rate Descriptive Statistics for ETL Spa 2001 Showerhead Installations $(n=80)$

\begin{tabular}{|l|c|c|c|}
\hline & Water Pressure & Pre-Flow & Post-Flow \\
\hline Mean & 60.7 & 3.09 & 1.67 \\
\hline Standard Deviation & 17.9 & 1.34 & 0.26 \\
\hline
\end{tabular}

IABLE 3.5. Water Pressure and Pre- and Post-Installation Flow Rate Descriptive Statistics for Ondine Showerhead Installations $(n=13)$

\begin{tabular}{|l|c|c|c|}
\hline & $\begin{array}{c}\text { Water Pressure } \\
\left(1 \mathrm{~b} / \mathrm{in}^{2}\right)\end{array}$ & $\begin{array}{c}\text { Pre-flow } \\
(\mathrm{ga} / \mathrm{min})\end{array}$ & $\begin{array}{c}\text { Post-Flow } \\
(\mathrm{ga} / \mathrm{min})\end{array}$ \\
\hline Mean & 57.7 & 3.89 & 2.55 \\
\hline Standard Deviation & 18.7 & 1.21 & 0.24 \\
\hline
\end{tabular}

IABLE 3.6. Pearson and Spearman Correlation Coefficients for Pressure, Flows, and Change in Flow for ETL Spa 2001 Showerhead Installations $(n=80)$

\begin{tabular}{|l|c|c|c|c|}
\hline & Pressure & Pre-Flow & Post-Flow & $\begin{array}{c}\text { Change } \\
\text { (pre-post) }\end{array}$ \\
\hline \multicolumn{5}{|l|}{ Pearson Coefficients } \\
\hline Pressure & 1.00 & & & \\
\hline Pre-Flow & 0.41 & 1.00 & & \\
\hline Post-Flow & 0.58 & 0.39 & 1.00 & \\
\hline Change (Post-Pre) & 0.31 & 0.98 & .20 & 1.00 \\
\hline Spearman Coefficients & & & & \\
\hline Pressure & 1.00 & & & \\
\hline Pre-Flow & 0.42 & 1.00 & & \\
\hline Post-Flow & 0.59 & 0.38 & 1.00 & \\
\hline Change (Post-Pre) & 0.37 & 0.97 & .20 & 1.00 \\
\hline
\end{tabular}


IABLE 3.7. Pearson and Spearman Correlation Coefficients for Pressure, Flows, and Change in Flow for Ondine Showerhead

Installations $(n=13)$

\begin{tabular}{|l|c|c|c|c|}
\hline & Pressure & Pre-Flow & Post-Flow & Change (pre-post) \\
\hline \multicolumn{5}{|l|}{ Pearson Coefficients } \\
\hline Pressure & 1.00 & & & \\
\hline Pre-Flow & 0.47 & 1.00 & & \\
\hline Post-Flow & 0.55 & 0.43 & 1.00 & \\
\hline Change (Post-Pre) & 0.38 & 0.98 & .25 & 1.00 \\
\hline Spearman Coefficients & 1.00 & & & \\
\hline Pressure & 0.46 & 1.00 & & \\
\hline Pre-Flow & 0.53 & 0.42 & 1.00 & \\
\hline Post-Flow & 0.33 & 0.96 & .24 & 1.00 \\
\hline Change (Post-Pre) &
\end{tabular}

Another conclusion that can be drawn from Tables 3.4 through 3.7 is that existing showerheads have a greater variation in flow rates than retrofit showerheads. The causes for the greater variation in pre-flow rates are unknown, but could be attributed to one or a combination of the following. First, the existing showerheads reflect a variety of showerhead types and flow rates. This heterogeneity by itself would lead to greater variation in flow rates when compared to a single model of showerhead. Second, a relatively large fraction of the existing showerheads had measured flows that would place them in the category of "low-flow" showerheads, although they were not "lowflow" models. It is possible that these showerheads had lower flow rates because they became fouled by scale, rust, and other debris carried in the water line over time. Finally, 26 of the 173 showerheads were characterized as "energy efficient" by participants. Seventy of the 173 showerheads were not classified and the participants were "unsure" about the efficiency of 36 . Both of these categories could include additional energy-efficient showerheads (see Table 3.1). If this is the case, the low-flow observations may include a large fraction of existing showerheads that are already low-flow models. 


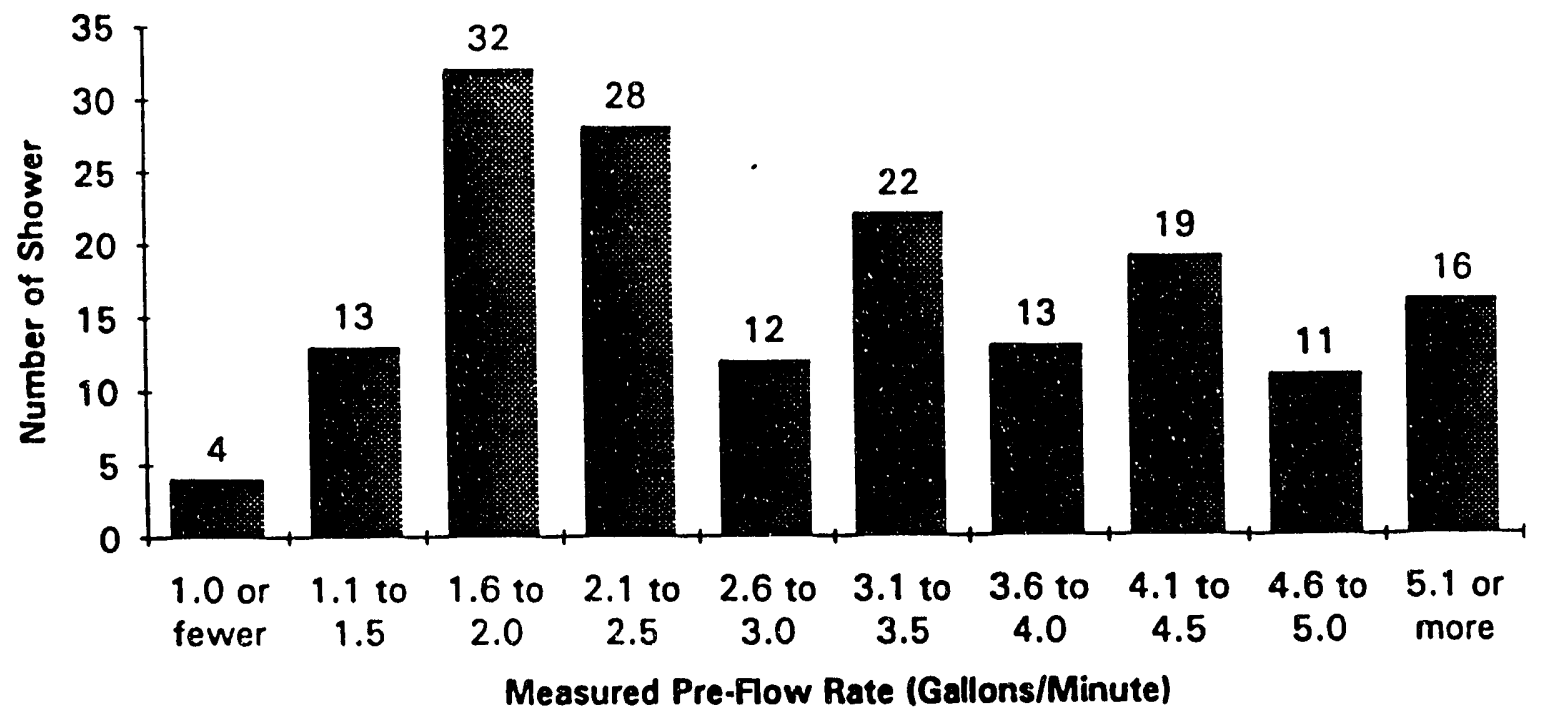

\begin{tabular}{|c|c|c|c|c|c|c|c|c|c|}
\hline \multicolumn{10}{|c|}{ Cumulative Frequency of Showerheads } \\
\hline 170 & 166 & 153 & 121 & 93 & 81 & 59 & 46 & 27 & 16 \\
\hline
\end{tabular}

EIGURE 3.3. Distribution of Measured Pre-Flow Rates 
IABLE 3.8. Showerhead Savings Estimates at Various Retrnfit Flow Rates

\begin{tabular}{|c|c|c|}
\hline $\begin{array}{c}\text { Design Flow Rate of } \\
\text { Retrofit Showerhead } \\
(\mathrm{gpm})\end{array}$ & $\begin{array}{c}\text { Number of Showerheads } \\
\text { with Savings (base 170) }\end{array}$ & $\begin{array}{c}\text { Fraction of Showerheads } \\
\text { with Savings (170=100\%) }\end{array}$ \\
\hline 3.0 & 81 & $48 \%$ \\
\hline 2.5 & 93 & 55 \\
\hline 2.0 & 121 & 71 \\
\hline 1.5 & 153 & 90 \\
\hline 1.0 & 166 & 98 \\
\hline
\end{tabular}

Whatever the reason, existing showerhead flow rates in this sample vary significantly from the expected rate of 4 to $5 \mathrm{gpm}$, with a large fraction substantially below that level. This raises questions about energy savings estimates based on assumed average flow rates of between 4 and $5 \mathrm{gpm}$. Nevertheless, similar savings could be achieved with showerheads that provide the same flow rate reduction. For example, flow rate reductions of $1.5 \mathrm{gpm}$ could be achieved from a $2.5 \mathrm{gpm}$ showerhead with average flows of $4 \mathrm{gpm}$. If average flows are actually $3.1 \mathrm{gpm}$, as verified in this study, this $1.5-\mathrm{gpm}$ reduction would require a showerhead that performed at a $1.6 \mathrm{gpm}$ rate.

The mean water pressure for sites in the showerhead installation study was 60.3 psi (Table 3.4). The variety of showerheads and consequent range in flow rates confounds correlations of pre-flow rates with water pressure. When only one model of showerhead is used, the deviations associated with pressure are significantly reduced. This probably indicates that modern showerheads are designed to function satisfactorily across a broad range of water pressures. This conclusion is reinforced when the sample is grouped by low, medium, and high water pressure (see Table 3.9). Table 3.9 also illustrates that "low" water pressures are associated with noticeable reductions in both pre- and post-installation flow rates and subsequent water savings. "Low" water pressures were often associated with households using wells for the water supply (see Table 3.10). 
IABLE 3.9. Water Pressure and Flow Rates for the Total Sample and by Low, Medium, and High Water Pressure Groupings (ETL Spa 2001 sites only)

\begin{tabular}{|l|r|r|r|r|}
\hline Total $(n=80)$ & $\begin{array}{l}\text { Water Pressure } \\
(\mathrm{psi})\end{array}$ & $\begin{array}{l}\text { Pre-Flow } \\
(\mathrm{gpm})\end{array}$ & $\begin{array}{l}\text { Post-Flow } \\
(\mathrm{gpm})\end{array}$ & $\begin{array}{l}\text { Difference } \\
(\mathrm{gpm})\end{array}$ \\
\hline Mean & 60.7 & 3.09 & 1.67 & 1.42 \\
\hline Standard Deviation & 17.9 & 1.34 & 0.26 & 1.26 \\
\hline
\end{tabular}

\begin{tabular}{|l|r|r|r|r|}
\hline $\begin{array}{l}\text { Low Pressure } \\
(n=18)\end{array}$ & $\begin{array}{l}\text { Water Pressure } \\
(\mathrm{psi})\end{array}$ & $\begin{array}{l}\text { Pre-Flow } \\
(\mathrm{gpm})\end{array}$ & $\begin{array}{l}\text { Post-Flow } \\
(\mathrm{gpm})\end{array}$ & $\begin{array}{l}\text { Difference } \\
(\mathrm{gpm})\end{array}$ \\
\hline Mean & 36.6 & 2.33 & 1.41 & 0.92 \\
\hline Standard Deviation & 4.2 & 1.06 & 0.17 & 0.99 \\
\hline
\end{tabular}

\begin{tabular}{|l|r|r|r|r|}
\hline $\begin{array}{l}\text { Medium Pressure } \\
(n=34)\end{array}$ & $\begin{array}{l}\text { Water Pressure } \\
\text { (psi) }\end{array}$ & $\begin{array}{l}\text { Pre-Flow } \\
(\mathrm{gpm})\end{array}$ & $\begin{array}{l}\text { Post-Flow } \\
\text { (gpm) }\end{array}$ & $\begin{array}{l}\text { Difference } \\
(\mathrm{gpm})\end{array}$ \\
\hline Mean & 57.5 & 3.10 & 1.70 & 1.40 \\
\hline Standard Deviation & 6.4 & 1.34 & 0.20 & 1.35 \\
\hline
\end{tabular}

\begin{tabular}{|l|r|r|r|r|}
\hline $\begin{array}{l}\text { High Pressure } \\
(\mathrm{n}=28)\end{array}$ & $\begin{array}{l}\text { Water Pressure } \\
(\mathrm{psi})\end{array}$ & $\begin{array}{l}\text { Pre-Flow } \\
(\mathrm{gpm})\end{array}$ & $\begin{array}{l}\text { Post-Flow } \\
(\mathrm{gpm})\end{array}$ & $\begin{array}{l}\text { Difference } \\
(\mathrm{gpm})\end{array}$ \\
\hline Mean & 80.0 & 3.56 & 1.80 & 1.76 \\
\hline Standard Deviation & 9.4 & 1.32 & 0.28 & 1.24 \\
\hline
\end{tabular}

IABLE 3.10. Water Pressure for Sites With and Without a Well

\begin{tabular}{|l|c|c|c|}
\hline & Number of Sites & $\begin{array}{c}\text { Average Water } \\
\text { Pressure (psi) }\end{array}$ & $\begin{array}{c}\text { Standard } \\
\text { Deviation }\end{array}$ \\
\hline All Sites (a) & 96 & 60.50 & 17.72 \\
\hline No Well & 77 & 66.08 & 14.98 \\
\hline With Well & 19 & 37.89 & 6.08 \\
\hline $\begin{array}{l}\text { (a) Water source was not asked of all participants. } \\
\text { were constructed from other sources (see Table 1.1) for a total } \\
\text { of 96 sites. }\end{array}$ \\
\hline
\end{tabular}




\subsection{OCCUPANT CHARACTERISTICS}

Data on the number of occupants by age group and information on occupants' use of hot water for showering and other household uses were collected using the field report survey form (Appendix A) and are reported below. The REMP survey performed in 1991 had obtained similar data, which are provided for comparison.

\subsubsection{Profile of Site Occupants}

The 1992 results on the number of occupants indicated that a total of 293 persons lived at the 105 sites visited. The maximum number of persons in any of the sites was eight. About $10 \%$ (11) of the sites were occupied by a single person and $47 \%$ (49) were occupied by two persons. About $43 \%$ of the sites were occupied by three or more persons. A breakdown of the number of persons per site is shown in Table 3.11.

Age and sex are often used to explain iathing water use differences among households. Females and school-age childreis are associated with higherthan-average hot water use. Of the 296 occupants, 145 (49\%) were male and 151 (51x) were female.

The data on occupant age were distributed by age group as follows:

- 26 (9\%) were less than 6 years old

- $59(20 \%)$ were 6 to 17 years old

- $191(65 \%)$ were 18 to 64 years old

- 20 (7\%) were 65 or older.

These age group categories are the age groupings that were used for the ELCAP study.

of the 11 single-person households, five were occupied by retirement-age persons and the remaining six were occupied by working-age persons. Of the two-person households, only one consisted of a combination of a school-age occupant and a person over 17 (i.e., a single-parent household). The remaining 96 persons in the 48 two-occupant households were all working or retirement-age persons. Responses to occupancy-type questions were received 
for 247 persons. Of these, 235 (95\%) were categorized as full-time occupants, 8 (3\%) as part-time occupants, and $4(2 \%)$ as summer occupants.

TABLE 3.11. Number of Occupants per Site

\begin{tabular}{|c|c|c|}
\hline $\begin{array}{c}\text { Number of Persons } \\
\text { Occupying Site }\end{array}$ & $\begin{array}{c}\text { Number of } \\
\text { Sites }\end{array}$ & Percent of Sites \\
\hline 1 & 11 & 10 \\
\hline 2 & 49 & 47 \\
\hline 3 & 14 & 13 \\
\hline 4 & 15 & 14 \\
\hline 5 & 13 & 12 \\
\hline 6 & 2 & 2 \\
\hline 7 & 0 & 0 \\
\hline 8 & 1 & 1 \\
\hline
\end{tabular}

A similar analysis was done for REMP to compare nonparticipants to participants in terms of the number-of-persons data from the 1991 REMP/ELCAP survey. The results for the mean number of persons per age category are shown in Table 3.12. The table also includes the mean number of persons based on the 1992 survey. The number of participants for whom 1991 data was available was 77 .

These analyses indicate that the participants in the field study are similar to non-participants. This indicates that the recruitment methods used did not introduce any significant bias. These descriptive statistics can also be used to compare the REMP and field study participants to other samples. Such comparisons are planned in the energy savings analysis portion of this study and are expected to identify possible limits to extrapolation of results from this sample. 
IABLE 3.12. Comparison of Participants and Non-Participants in Terms of Their 1991 and 1992 Survey Mean Number of Persons by Age Category

\begin{tabular}{|l|c|c|c|}
\hline \multicolumn{1}{|c|}{ Age Category } & $\begin{array}{c}\text { Nonparticipants } \\
\text { 1991 Survey } \\
\text { (N=68) }\end{array}$ & $\begin{array}{c}\text { Participants } \\
\text { 1991 Survey } \\
\text { (N=77) }\end{array}$ & $\begin{array}{c}\text { Participants } \\
\text { 1992 Survey } \\
\text { (N=77) }\end{array}$ \\
\hline Very young & 0.22 & 0.25 & 0.23 \\
\hline School age & 0.57 & 0.45 & 0.45 \\
\hline Working age & 1.59 & 1.82 & 1.78 \\
\hline Retirement age & 0.41 & 0.26 & 0.23 \\
\hline $\begin{array}{l}\text { Total persons } \\
\text { per home }\end{array}$ & 2.79 & 2.78 & 2.70 \\
\hline
\end{tabular}

\subsubsection{Erequency of Showering ard Other Hot-Water Usages}

Participants were asked how frequently each of the showers in the home were used. The term "frequently" was used to classify responses for "four or more times per week." Re:sponses to this question indicate that participants prefe:red showers to tub baths for bathing. Table 3.13 provides descriptive data on the sites and number of showers: 121 of the 173 showers (or 70\%) are used frequently, at least four times per week. The number of showers in the home is related to frequency of shower usage. A decrease in usage associated with having multiple showers is clear in Table 3.13. This probably reflects "surplus" showering capacity. Nevertheless, idle showering capacity affects the cost of measures to reduce water flow and save energy from showers.

To ensure water flow reductions at a site, all showerheads should be replaced. However, Table 3.13 indicates that the frequency of use per shower declines as the number of showers in the home increases. As a result, the incremental water and energy savings associated with more than one showerhead retrofit per home would also decline. The water saved in the "first" shower would be nearly twice that associated with showerhead retrofits in the "third" shower according to Table 3.13 ( $89 \%$ use rate compared to 52\%). However, the cost of the showerhead measure would be the same for each shower. As a result, the cost of the water and energy saved in the "third" shower would be 
nearly twice that of "first" shower on a cost per unit (i.e., showerhead replaced or gallon or kilowatt-hour) basis.

The number of showers per household per week is shown along with other household water uses in Table 3.14. The data is based on responses to the 1991 survey of REMP subjects. These subjects formed the population from which the sample for this study was talen. For comparison, the results are presented for sites that participated in the showerhead installation study and for nonparticipants, sites that were not in the installation study but were in the 1991 REMP study.

\subsection{SITE CHARACTERISTICS}

Data were collected on participants' water heaters and household devices that used hot water. This data was collected to place shower water use into the context of total hot water use. Energy use by water heaters serves two primary purposes. The first of these is to heat incoming water from a well or central water supply to a pre-set temperature for later use as hot water.

TABLE 3.13. Shower Usage

\begin{tabular}{|r|r|r|r|r|r|}
\hline $\begin{array}{c}\text { Showers } \\
\text { per Site }\end{array}$ & $\begin{array}{r}\text { No. of } \\
\text { Sites }\end{array}$ & $\begin{array}{c}\text { No. of } \\
\text { Showers }\end{array}$ & $\begin{array}{c}\text { No. Used } \\
\text { Frequently }\end{array}$ & $\begin{array}{c}\text { No. Used } \\
\text { Infrequently }\end{array}$ & $\begin{array}{c}\text { Percent Used } \\
\text { Frequently }\end{array}$ \\
\hline 1 & 47 & 47 & 39 & 5 & $89 \%$ \\
\hline 2 & 48 & 96 & 68 & 28 & $71 \%$ \\
\hline 3 & 10 & 30 & 14 & 13 & $52 \%$ \\
\hline Total & 105 & 173 (a) & 121 & 46 & \\
\hline (a) Frequency of use data was missing for 6 of these showers. \\
\hline
\end{tabular}


IABLE 3.14. Household Showers and Other Hot Water Uses per Week (number in parentheses - the number of cases that had data for that variable; the source for this data is the 1991 REMP survey)

\begin{tabular}{|l|c|c|c|c|}
\hline \multirow{2}{*}{ Hot Water Uses } & \multicolumn{2}{|c|}{ REMP Nonparticipants } & \multicolumn{2}{|c|}{ REMP Participants } \\
\cline { 2 - 5 } & Mean & $\begin{array}{c}\text { Standard } \\
\text { Deviation }\end{array}$ & Mean & $\begin{array}{c}\text { Standard } \\
\text { Deviation }\end{array}$ \\
\hline Number of showers per week & $\begin{array}{c}12.0 \\
(64)\end{array}$ & 8.2 & $\begin{array}{c}12.4 \\
(75)\end{array}$ & 7.42 \\
\hline $\begin{array}{l}\text { Number of loads of dishes } \\
\text { washed }\end{array}$ & $\begin{array}{c}5.7 \\
(61)\end{array}$ & 3.85 & $\begin{array}{c}5.4 \\
(69)\end{array}$ & 3.22 \\
\hline $\begin{array}{l}\text { Number of loads of clothes } \\
\text { washed }\end{array}$ & $\begin{array}{c}6.3 \\
(65)\end{array}$ & 5.16 & $\begin{array}{c}6.6 \\
(74)\end{array}$ & 3.88 \\
\hline $\begin{array}{l}\text { Number of loads of clothes } \\
\text { washed in cold water }\end{array}$ & $\begin{array}{c}2.4 \\
(52)\end{array}$ & 2.52 & $\begin{array}{c}2.9 \\
(63)\end{array}$ & 3.58 \\
\hline $\begin{array}{l}\text { Number of loads of clothes } \\
\text { rinsed in cold water }\end{array}$ & $\begin{array}{c}5.6 \\
(58)\end{array}$ & 5.27 & $\begin{array}{c}6.4 \\
(65)\end{array}$ & 4.19 \\
\hline
\end{tabular}

This water is typically stored rather than heated for immediate use. As a result, the water heater also has to maintain the temperature of the heated water until it is withdrawn. Hot water in the water heater constantly cools because the hot water is much warmer than the surrounding air and the water heater jacket is not a perfect insulator. The heat lost in this manner is called "standby loss." The water heater has to periodically heat-up the stored water to keep it at the desired temperature to compensate for the standby losses. Hot water energy conservation potential can be realized by reducing either standby losses or hot water use or both.

\subsubsection{Participants' Water Heaters}

The water heater is the source for almost all hot water used in a house. The age and location of a water heater plays a significant role in the amount of energy used by the water heater for standby heating. New water heaters are better insulated, on average, than older water heaters due to recent changes in appliance efficiency standards. Water heaters that are located in areas of the home that are heated use less energy to maintain heated water at preset temperatures due to the buffering effect of the warmer air. In contrast, water heaters located in areas that are not specifically heated for use as 
living space ("unheated or unconditioned" space), typically lose more heat to the colder surrounding air and inerefore require more energy to maintain water temperature. Locating the water heater in a closet or similar e:.slosure also insulates the water heater from loss of heat. Xey characteristics for water heaters among both REAP non-participants and field study participints are presented on Table 3.15. The two REMP sub-samnles have similar characteristics, again indicating little bias in either the sample or recruitment method.

Most of trie field study homes (95\%) had only one water heater (Table 3.17). It was likely to be an electrically operated water heater that was between 1 and 10 years old and was located in a small, enciosed space in an unheated part of the house. In $62 \%$ of the cases the water heater was $n=\hat{c}$ wrapped, in $78 \%$ the pipes were not wrappeo with insulation, $67 \%$ were not on an insulating floor mat, and $94 \%$ did not have a heat trap (Tables 3.15, 3.16, and 3.17$)$.

The REMP sites used for this f:eld study were selecied because they were mostly a:i electric homes; they used electricity for space heating and cooking and were required to have at least one electric water heater. As a result, the high fraction of electric water heiters was expected.

IABLE 3.15. Comparison of Participant and Nonparticipant Data on Water Heaters

\begin{tabular}{|l|c|c|}
\hline & $\begin{array}{c}\text { Participants } \\
(N=77)\end{array}$ & $\begin{array}{c}\text { Nonparticipants } \\
(N=66)\end{array}$ \\
\hline $\begin{array}{l}\text { Had replaced or added a water heater } \\
\text { since } 1985\end{array}$ & $22(29 \%)$ & $21(31 \%)^{(a)}$ \\
$\begin{array}{l}\text { Water heater located in a small } \\
\text { enclosed space }\end{array}$ & $61(79 \%)$ & $45(68 \%)$ \\
\hline Water heater located in a heated area & $38(50 \%)$ & $27(41 \%)^{(b)}$ \\
\hline (a) Data mi ssing for two nonparticipants \\
\hline (b) Data missing ior three nonparticipants \\
\hline
\end{tabular}


IABLE 3,16. Hater Heater Fuel by Type of Area Served (for sites in field installation study)

\begin{tabular}{|l|c|c|c|c|}
\hline Water Heater Fuel & Missing & $\begin{array}{c}\text { Area Served (Less } \\
\text { Than Whole(e) }\end{array}$ & Whole & Total \\
\hline Missing & 0 & 0 & 1 & 1 \\
\hline Electric & 2 & 6 & 94 & 102 \\
\hline Gas & 1 & 0 & 6 & 7 \\
\hline Solar & 0 & 0 & 2 & 2 \\
\hline Total & 3 & 6 & 103 & 112 \\
\hline
\end{tabular}

(a) One each of the six water heaters serving less than the whole area of the site served an area defined as "bottom half," "down stairs," "master bath," "rest of house," "upper half," or "upstairs."

IABLE 3.17. Water Heater Descriptive Data for 95 Electric Water Heaters at 91 Participating Sites (field installation study)

\begin{tabular}{|c|c|c|}
\hline & Number of Water Heaters & Percent of Water Heaters \\
\hline \multicolumn{3}{|l|}{ Copacity (oallons) } \\
\hline Less than 50 & 6 & $7 \%$ \\
\hline 50 or 52 & 67 & $80 \%$ \\
\hline Greater than 52 & 10 & $12 \%$ \\
\hline Plissing data & 12 & - \\
\hline \multicolumn{3}{|l|}{ Age (years) } \\
\hline New to 5 & 22 & $37 \%$ \\
\hline 5 to 10 & 15 & $25 \%$ \\
\hline 11 to 15 & 13 & $22 \%$ \\
\hline 16 to 20 & 3 & $5 \%$ \\
\hline Over 20 & 6 & $10 \%$ \\
\hline Missing data & 36 & - \\
\hline \multicolumn{3}{|c|}{ In conditioned space? (a) } \\
\hline No & 42 & $.15 \%$ \\
\hline Yes & 51 & $55 \%$ \\
\hline Missing data & 2 & - \\
\hline
\end{tabular}




\begin{tabular}{|c|c|c|}
\hline \multicolumn{3}{|l|}{ Wrapped? } \\
\hline No & 59 & $62 \%$ \\
\hline Yes & 36 & $38 \%$ \\
\hline Missing data & 0 & - \\
\hline \multicolumn{3}{|l|}{ Has floor mat? } \\
\hline No & 64 & $67 \%$ \\
\hline Yes & 31 & $33 \%$ \\
\hline Missing data & 0 & - \\
\hline \multicolumn{3}{|c|}{ Had pipe wrapped? } \\
\hline No & 74 & $78 \%$ \\
\hline Yes & 21 & $22 \%$ \\
\hline Missing data & 0 & - \\
\hline \multicolumn{3}{|c|}{ Had heat trap (coill? } \\
\hline No & 89 & $94 \%$ \\
\hline Yes & 6 & $6 \%$ \\
\hline Missing data & 0 & - \\
\hline \multicolumn{3}{|c|}{ Served whole horne? } \\
\hline No & 6 & $6 \%$ \\
\hline Yes & 88 & $94 \%$ \\
\hline Missing data & 1 & - \\
\hline \multicolumn{3}{|c|}{ More than one electric water heater? } \\
\hline No & 100 & $96 \%$ \\
\hline Yes & 4 & $4 \%$ \\
\hline Missing data & 1 & - \\
\hline
\end{tabular}

Wrapping water heaters with additional insulation to save energy is a common conservation measure. This measure has been included in utility conservation programs for many years. As a result, the relatively low fraction of water heaters that had additional insulation is somewhat of a surprise. Additional insulation is not recommended for some new water heater models and this may be a partial explanation. Insulating floor mats and 
insulation or heat traps on water pipes are also standard conservation measures. The relatively low rate for these measures is also unexpected. These observations indicate that significant potential for retrofit measures for water heaters and subsequent energy savings, still remain. It is useful to note in this context that two of the homes had solar water heaters despite the fact that no institutional programs to promote or install solar water heaters currently operate in the region.

\subsubsection{Non-Shower Hot-Water Using Devices}

Section 3.3.1 discussed characteristics of water heaters, such as location, that affected standby losses. Information on hot-water-using devices, other than showers, that could be found in participants' homes is presented in this section.

of the 91 participating households, all had sinks, all had clothes washing machines, 82 had dish washers, 1 had a hot tub, and 1 had a point-ofuse water heater. All of the houses had more than one sink: 13 houses had two sinks each, 44 had three sinks each, 21 had four sinks each, 11 had five sinks each, and 2 had six sinks. Hot water boosters were found with some of the appliances (see Table 3.18).

IABLE 3.18. Use of Hot Water Booster with Non-Shower Hot Water Using Devices

\begin{tabular}{|l|c|c|c|c|c|c|}
\hline $\begin{array}{l}\text { Booster } \\
\text { Present }\end{array}$ & Sinks & $\begin{array}{c}\text { Clothes } \\
\text { Washers }\end{array}$ & $\begin{array}{c}\text { Dish } \\
\text { Washers }\end{array}$ & $\begin{array}{c}\text { Hot } \\
\text { Tubs }\end{array}$ & $\begin{array}{c}\text { Point of } \\
\text { Use Heaters }\end{array}$ & Total \\
\hline No & 0 & 86 & 44 & 0 & 0 & 130 \\
\hline Yes & 0 & 1 & 36 & 0 & 0 & 37 \\
\hline Not Apply & 91 & 0 & 0 & 1 & 1 & 93 \\
\hline Missing & 0 & 4 & 2 & 0 & 0 & 6 \\
\hline Total & 0 & 87 & 80 & 1 & 1 & 167 \\
\hline
\end{tabular}




\subsection{POST-INSTALLATION TELEPHONE SURVEY}

Data and results in the preceding chapter were based on the initial site inspections and showerhead retrofit visits. A telephone survey was conducted approximately six months after completion of the showerhead installation and field data collection. Data on use of, and attitudes toward, the showerheads and changes that might influence the energy consumption results were the focus of this survey.

\subsection{POST-INSTALLATION TELEPHONE SURVEY METHOD}

PNL staff in Richland, Washington, conducted a telephone survey approximately six months after installation of the showerheads. A primary purpose of the survey was to collect information about whether the energyefficient showerheads were still in place and to determine attitudes toward the showerheads. Other purposes were to collect data on

- the frequency of showering and other uses of not water

- changes at the site that might influence showering or hot water consumption

- other variables that might influence the energy consumption results.

The survey questions included the following:

- whether any showerhead(s) had been replaced

- attitudes toward showerheads based on a 10-point rating scale

- whether the showerhead flow control valve was used

- water or money savings

- the number of showers taken and their duration

- the number of baths taken

- changes in the

1) frequency or duration of showers

2) hot water heater

3) number of persons occupying the site 
- the number of loads of dishes and clothes washed (total and in cold water)

- how frequently the household ran out of hot water

- whether the site used city water or had a well.

The telephone survey data collection began in March 1992 and continued through August. PNL staff telephoned each site and, reading from a script, asked to talk to an adult at the site (please see Appendix $D$ for a copy of the introductory script and the survey instrument used). When an acceptable respondent was on the phone, the surveyor proceeded to ask the questions as shown on the survey form.

The mean number of days between showerhead installation and completion of the telephone interview was 233 days ( $S D=37$ days) with a minimum of 155 days (about 5.1 months) and a maximum of 307 days (about 10.1 months). occupants at all sites had ample time to have experience with the showerheads and to request return of their original showerheads if they were not satisfied.

\subsection{PARTICIPANT SATISFACTION WITH SHOWERHEADS}

Table 4.1 shows the means and standard deviations of data from five showerhead satisfaction items. The statistics were calculated using the data from 80 sites having complete data on all five items. The respondents had been asked to use a scale ranging from 1 to 10 , where 1 was "not at all satisfied" and 10 was "very satisfied," in responding to the questions. The average ratings generally fell about 7.6, midway between a neutral 5.0 and the most favorable rating of 10.0 . The most favorable mean rating was for the appearance of the showerheads, at 8.0. The overall rating was the lowest, at 7.4. This lowest overall rating suggests that there may be features of the showerheads not tapped by the other satisfaction items which resulted in a lowering of the overall satisfaction with the showerheads. The ratings for water volume, water force, and sound of the showerheads were about the same at 7.7 or 7.6 .

It should be noted that participants in this study were not given a choice of showerhead. The primary showerhead installed, the ETL Spa 2001, was 
selected based on its performance. The ETL Spa 2001 rated lower than other showerheads in other studies of showerhead satisfaction (Katzev 1991). Further, anecdotal evidence from large-scale installation programs indicates that consumers have both strong positive and negative reactions to the ETL Spa 2001. Criticisms primarily focus on the force of the shower stream and the "roar" or loud noise associated with it. The fact that participants in this study reacted favorably is significant given they had no choice and that consumers generally favored other showerheads when given a choice.

IABLE 4.1. Means and Standard Deviations for Five Showerhead Satisfaction Items $(n=80)$

\begin{tabular}{|l|c|c|}
\hline Satisfaction Item & Mean & Standard Deviation \\
\hline Overall & 7.6 & 2.2 \\
\hline Water Volume & 7.9 & 2.1 \\
\hline Water Force & 7.8 & 2.2 \\
\hline Sounds & 7.8 & 2.2 \\
\hline Appearance & 8.1 & 2.0 \\
\hline
\end{tabular}

Table 4.2 shows frequency tabulations and percentages for other items related to the use of the showerheads and attitudes toward them. Percentages are given in terms of both those answering the question and the total number of sites (including "Don't know" and "Missing" cases).

The first results in Table 4.2 indicate that one or more showerheads had been replaced at six sites. The survey had asked participants, "On a scale from 1 to 10 , where 1 is 'not at all satisfied' and 10 is 'very satisfied,' how satisfied are you overall with the showerhead(s)?" Thirty-six respondents indicated some level of dissatisfaction. Only respondents who expressed dissatisfaction with the showerhead(s) were asked if they had replaced any showerhead(s). Of the 36 sites where there was some indication of dissatisfaction, only 6 , or $17 \%$, had replaced any showerhead(s). 
IABLE 4.2. Response Frequencies for a Variety of Telephone Survey Items

\begin{tabular}{|c|c|c|c|}
\hline Item & Freüuency & $\begin{array}{l}\text { Valid Data } \\
\text { Percentage }\end{array}$ & Total Sample \\
\hline $\begin{array}{l}\text { Replaced showe } \\
\text { Mo } \\
\text { Yes } \\
\text { Missing }\end{array}$ & $\begin{array}{r}30 \\
6 \\
48\end{array}$ & $\begin{array}{r}83 \\
17 \\
-\end{array}$ & $\begin{array}{r}36 \\
7 \\
57\end{array}$ \\
\hline $\begin{array}{l}\text { Use flow contr } \\
\text { Ho } \\
\text { Yes } \\
\text { Don't know } \\
\text { Missing }\end{array}$ & $\begin{array}{r}57 \\
23 \\
1 \\
3\end{array}$ & $\begin{array}{r}71 \\
29 \\
- \\
-\end{array}$ & $\begin{array}{r}68 \\
27 \\
1 \\
4\end{array}$ \\
\hline $\begin{array}{l}\text { Saved on cost } \\
\text { Not yet } \\
\text { Some } \\
\text { Don't know } \\
\text { Missing }\end{array}$ & $\begin{array}{r}32 \\
21 \\
29 \\
2\end{array}$ & $\begin{array}{r}60 \\
40 \\
- \\
-\end{array}$ & $\begin{array}{r}38 \\
25 \\
35 \\
2\end{array}$ \\
\hline $\begin{array}{l}\text { Saved on cost } \\
\text { Not yet } \\
\text { Some } \\
\text { Don't know } \\
\text { Missing }\end{array}$ & $\begin{array}{r}31 \\
15 \\
30 \\
8\end{array}$ & $\begin{array}{r}67 \\
33 \\
- \\
-\end{array}$ & $\begin{array}{l}37 \\
18 \\
36 \\
10\end{array}$ \\
\hline $\begin{array}{l}\text { Changed water } \\
\text { Ho } \\
\text { Yes } \\
\text { Don't know } \\
\text { Missing }\end{array}$ & $\begin{array}{r}63 \\
10 \\
1 \\
10\end{array}$ & $\begin{array}{r}86 \\
14 \\
- \\
-\end{array}$ & $\begin{array}{r}75 \\
12 \\
1 \\
12\end{array}$ \\
\hline $\begin{array}{l}\text { Changed freque } \\
\text { of showers or } \\
\text { Ho } \\
\text { Yes } \\
\text { Don't know } \\
\text { Missing }\end{array}$ & $\begin{array}{r}76 \\
3 \\
0 \\
5\end{array}$ & $\begin{array}{r}96 \\
4 \\
- \\
-\end{array}$ & $\begin{array}{r}90 \\
0 \\
6\end{array}$ \\
\hline $\begin{array}{l}\text { Mumber of occu } \\
\text { changed } \\
\text { Ho } \\
\text { Increased } \\
\text { Decreased } \\
\text { Missing }\end{array}$ & $\begin{array}{r}76 \\
3 \\
2 \\
3\end{array}$ & $\begin{array}{r}94 \\
4 \\
-\end{array}$ & $\begin{array}{r}90 \\
4\end{array}$ \\
\hline
\end{tabular}

The second set of results indicates 29\% (20 of 69) of the respondents use the showerhead flow control valve. This feature was only on the ETL Spa 2001 and allows bathers to adjust the flow rate from full-on to nearly off at the showerhead. This feature provides the same function as using the shower valves to reduce or increase water flow but does so without disturbing the water temperature settings. This response indicates this is a desirable 
feature. If widely used, it could provide significant water and energy savings. Only eight respondents indicated how often they use the valve per week (see Table 4.3). However, their responses indicate its use as a matter of routine, mean use was 14.4 times per week.

The third and fourth set of responses reflect participant perceptions regarding water and energy savings. Results for the two items were very similar, with $31 \%$ reporting "some" water savings and $28 \%$ "some" electricity cost savings. However, most responded "don't know" or "not yet." The "not yet" category would, presumably, include those who felt they would save water or energy costs but had no concrete evidence. By this time, participants should have received between three and six electricity bills and between two and six water bills, so any savings should have been apparent.

The most surprising finding from the telephone survey was the number of changes, or replacements, of water heaters. Ten of 62 sites responding, or $28 \%$, indicated they had changed their water heater since showerhead installation. In contrast, the initial site visit resulted in 22 (or $37 \%$ ) responding that the water heater was "new to 5 years old" (Table 3.15). A 28\% replacement rate is a relatively high rate of change for such a short time period. It is possible that this high rate is due to inaccurate participant recall. The life of an electric water heater is typically between 10 and 15 years.

The remaining items on Table 4.2 report changes in the frequency or duration of showers and the number of persons living at the site. A high percentage of respondents indicated there were no changes. Only three respondents (4\%) reported a change in showering behavior. Changes in the number of persons living at the site were reported by five respondents (6\%). The net change in the number of persons living in the sites was a gain of two persons. 


\subsection{HOT WATER USES AND FREQUENCIES OF USE}

Table 4.3 contains the resuits for the survey items related to the shower and other water usage. Responses to all questions were not uniform. Accordingly, the valid number of responses is provided in the column after the question.

IABLE 4.3. Valid Number of Responses, Means, and Standard Deviations for Items Measuring Shower and Water Usage

\begin{tabular}{|c|c|c|c|}
\hline Item & $\begin{array}{l}\text { Valid } \\
\text { Number }\end{array}$ & Mean & $\begin{array}{r}\text { Standard } \\
\text { Deviation } \\
\end{array}$ \\
\hline $\begin{array}{l}\text { Number of times the shower } \\
\text { control valve is used } \\
\text { per week }\end{array}$ & 8 & 14.4 & 7.7 \\
\hline Number of showers per day & 83 & 2.6 & 2.8 \\
\hline Average shower duration & 81 & 7.5 & 3.7 \\
\hline Number of baths per day & 81 & 0.5 & 1.0 \\
\hline Shower frequency change & 1 & 3.0 & - \\
\hline Shower duration change & 2 & 5.0 & 7.1 \\
\hline Loads of dishes per week & 78 & 4.9 & 3.0 \\
\hline $\begin{array}{l}\text { Loads clothes washed per } \\
\text { week }\end{array}$ & 81 & 7.4 & .5 \\
\hline Loads washed in cold water & 82 & 2.6 & 4.8 \\
\hline Loads rinsed in cold water & 81 & 6.9 & 4.4 \\
\hline
\end{tabular}

The first item in Table 4.3, use of the showerhead control valve, was discussed above. The second item in the table shows that the mean number of showers taken (at 83 sites) was 2.6 per day (SD $=3.0$ ), or about one shower per day per person occupying the site (the mean number of persons per site was 2.8). The average shower duration reported by residents at 81 sites was found to be 7.4 minutes $(S D=3.8)$. This observation was within the range expected on the basis of other studies of self-reports of shower duration, but research indicates it may be 3 to 7 minutes less than metered results (Kempton 1984). 
The mean number of baths per day, based on data for 81 responses, was 0.5 baths per day $(S D=1.0)$. These results indicate a strong preference for showers over baths for bathing.

As noted in the preceding section, only a few of the respondents indicated they had changed their shower frequency or duration. Their detailed responses are provided in Table 4.3. The key point about this result is that few respondents indicated that any change had taken place.

The last four items on Table 4.3 contain the results for responses to questions about the number of loads of dishes and loads of clothes washed per week. The average number of loads of dishes washed was 5.1 (SD of 3.2) or less than one load per day. The number of loads of clothes washed per week was greater, at 7.6 loads per week (SD $=4.6)$, or roughly one load per day. of these, an average of 2.7 were washed in cold water and an average of 7.1 were rinsed in cold water. Most of the loads of clothes were rinsed in cold water. These findings should be helpful in subsequent analyses of energy savings as they indicate showering is one of the leading uses of hot water among the various major uses - tub baths and clothes and dish washing.

\subsection{MISCELLLANEOUS RESPONSES}

The telephone survey included several additional questions regarding hot water use and site characteristics. Results from two of these should be noted. The first is about how often participants run out of hot water. This is an important question as it could be a motive for participation in water efficiency programs. The second concerns the home's water source: a private well versus city water. Wells tend to have lower water pressures which translates into lower water flows and reduced water and energy savings from efficiency measures.

Table 4.4 contains results for the question, "On the average, how many times do you run out of hot water?" The results indicated that $72 \%$ of respondents (59 of 82 ) answered "never." Respondents at 23 of the sites indicated that they sometimes ran out of hot water. However, 10 of these 23 respondents answered "less than once per year," which is probably not a significant factor in their decisions about hot water use. Only 13 
respondents (16\% of 82 ) replied that they ran out of hot water once a year or more. Most of these responses clustered in the once-a-week or once-a-month range, which could provide significant motivation to participate in water heating efficiency programs.

IABLE 4.4. Number and Percent by Frequency of Running Out of Hot Water

\begin{tabular}{|l|c|c|c|}
\hline \multicolumn{1}{|c|}{ How Often Run Out? } & Frequency & $\begin{array}{c}\text { Valid Data } \\
\text { Percentage }\end{array}$ & $\begin{array}{c}\text { Total Sample } \\
\text { Percentage }\end{array}$ \\
\hline Once a day or more & 1 & 1 & 1 \\
\hline Once a week or more & 4 & 5 & 5 \\
\hline Once a month or more & 6 & 7 & 7 \\
\hline Once a year or more & 2 & 2 & 2 \\
\hline Less than once a year & 10 & 12 & 12 \\
\hline Never & 59 & 72 & 70 \\
\hline Don't know & 2 & -- & 2 \\
\hline
\end{tabular}

Table 4.5 contains the results on the source of the site's water supply. of 80 sites with data, $20 \%$ were supplied by their own well and the remaining $80 \%$ used city water.

IABLE 4.5. Number and Percent by Source of Water

\begin{tabular}{|l|c|c|c|}
\hline Water Source & Frequency & $\begin{array}{c}\text { Valid Data } \\
\text { Percentage }\end{array}$ & $\begin{array}{c}\text { Total Sample } \\
\text { Percentage }\end{array}$ \\
\hline Well & 16 & 20 & 19 \\
\hline City Water & 65 & 80 & 77 \\
\hline Missing & 3 & -- & 4 \\
\hline
\end{tabular}




\subsection{REFERENCES}

Katzev, R. 1991. "Does 'Low-Flow' Still Mean Low Satisfaction?" Home Energy, July/August.

Manclark, B. 1991. "Low-Flow Showers Save Water - Who Cares?" Home Energy, July/August.

Kempton, W. 1984. Residential Hot Water: A Behaviorally Driven System. Michigan State University. Cited by Public Power Council. March 1990. Evaluation of the Easy Savers Program. Prepared by Techplan Associates, Inc. Poughkeepsie, New York. 
APPENDIX A

\section{SHOWERHEAD RETROFIT INSTALLATION REPORT}




\section{SHOWERHEAD RETROFIT INSTALLATIUN REPORT (page 1)}

Site DI number:

Px number:

Hot Waier Heaters and Devices

\section{Water heater:}

Size (galions)

Model number

Age

Conditioned Space

Tank wrapped

Floor mat

Pipe wrapped

Heat trap

Electric/other (spec.)

Zones served
1

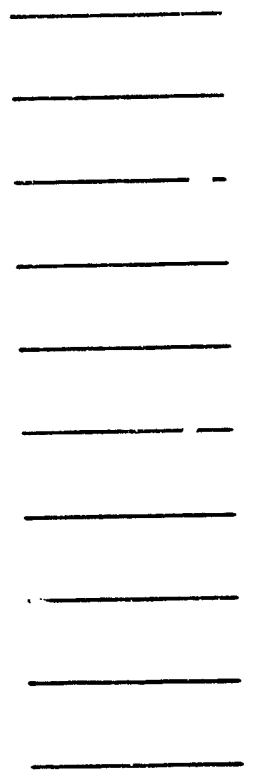

Hot Water Using Devices
Date:

Installer:
3

2
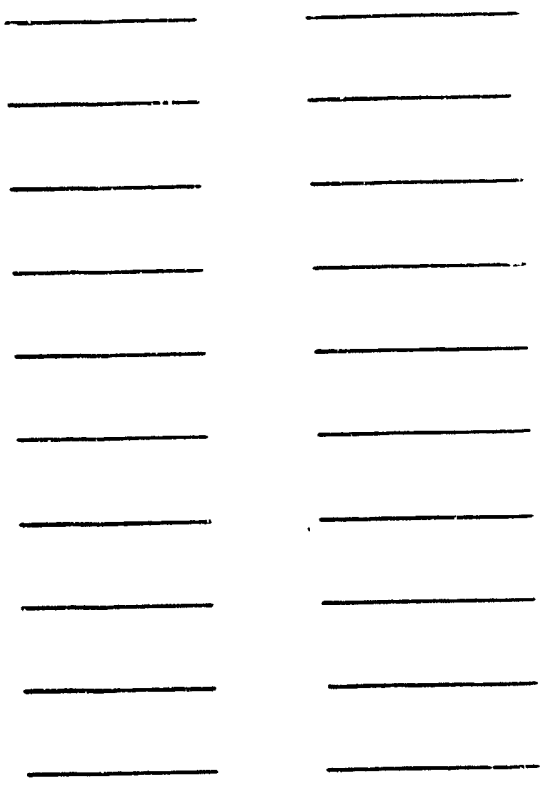

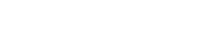


Location

Tub/Shower

Shower Only

other (specify)

Valve Fixtiures:

Single Valve Mixer

Sep. Hot/Cold Valves

Diverter Spout

other

Use Characteristics:

Frequent

Infrequent

Showerhead installed:

Diverter Valve:

Present

Replaced

Repaired/altered
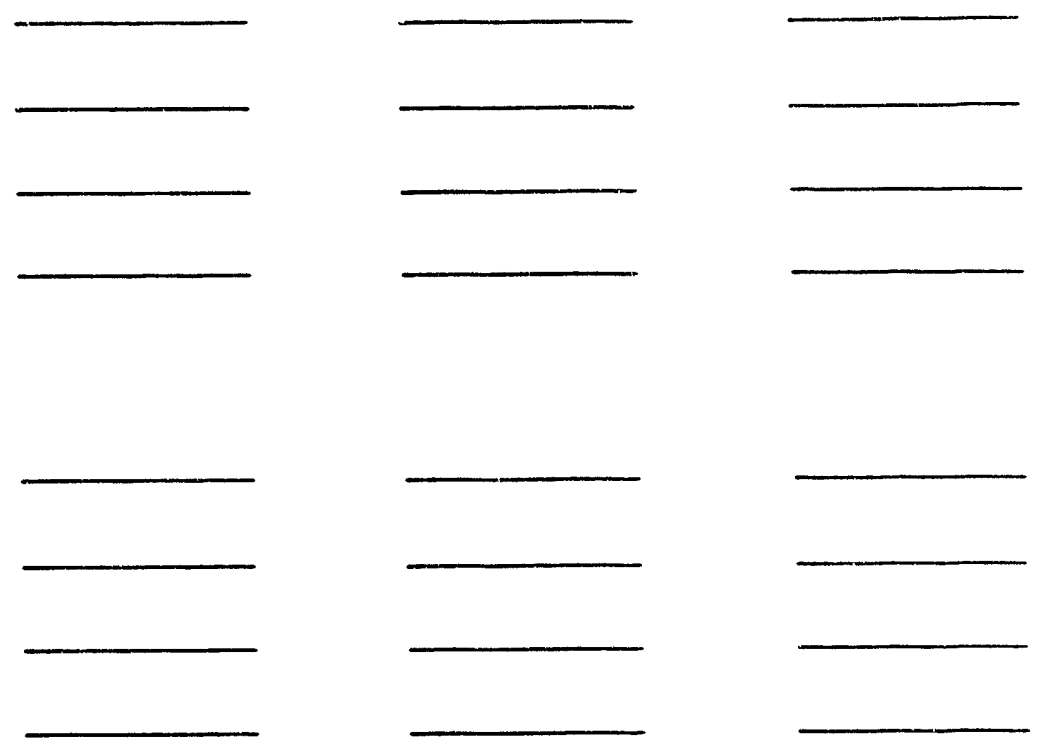


\section{SHOWERHEAD RETROFIT INSTALLATION REPORT (Dage 3)}

DI

PX

\section{FLOW TESTS}

SHOWER

SHOWER 2

SHOWER 3

Before Showerhead Installation

(Diverter spout NOT replaced)

\section{Full Flow:}

Through showerhead

By-pass through spout

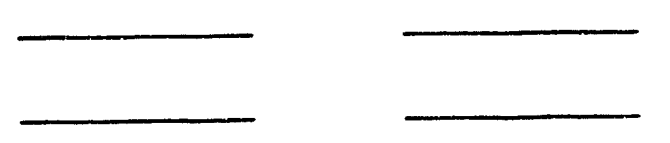

After Showerhead Installation (Diverter spout NOT replaced)

\section{Full Flow:}

Through showerhead

By-pass through spout

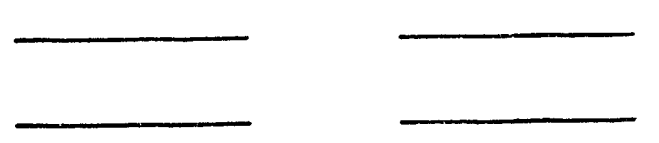

After Showerhead Installation.

(Diverter spout replaced)

\section{Eull Flow:}

Through showerhead

By-pass through spout 
SHOHERHEAD RETRUFIT INSTALLATION REPORT (page 4)

PX

\section{LIGHIING FIXTURE SURVEY}

Room Location
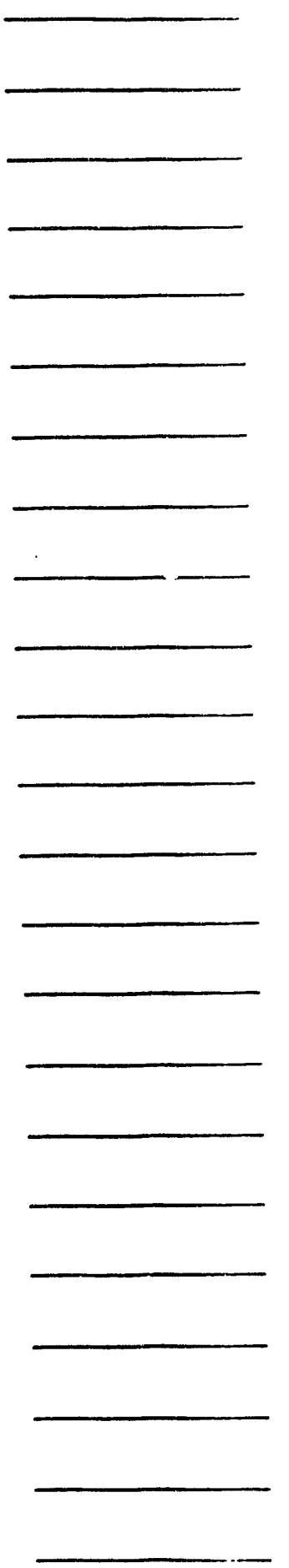

Number

Iype

\# of Bulbs \#Missing/Out
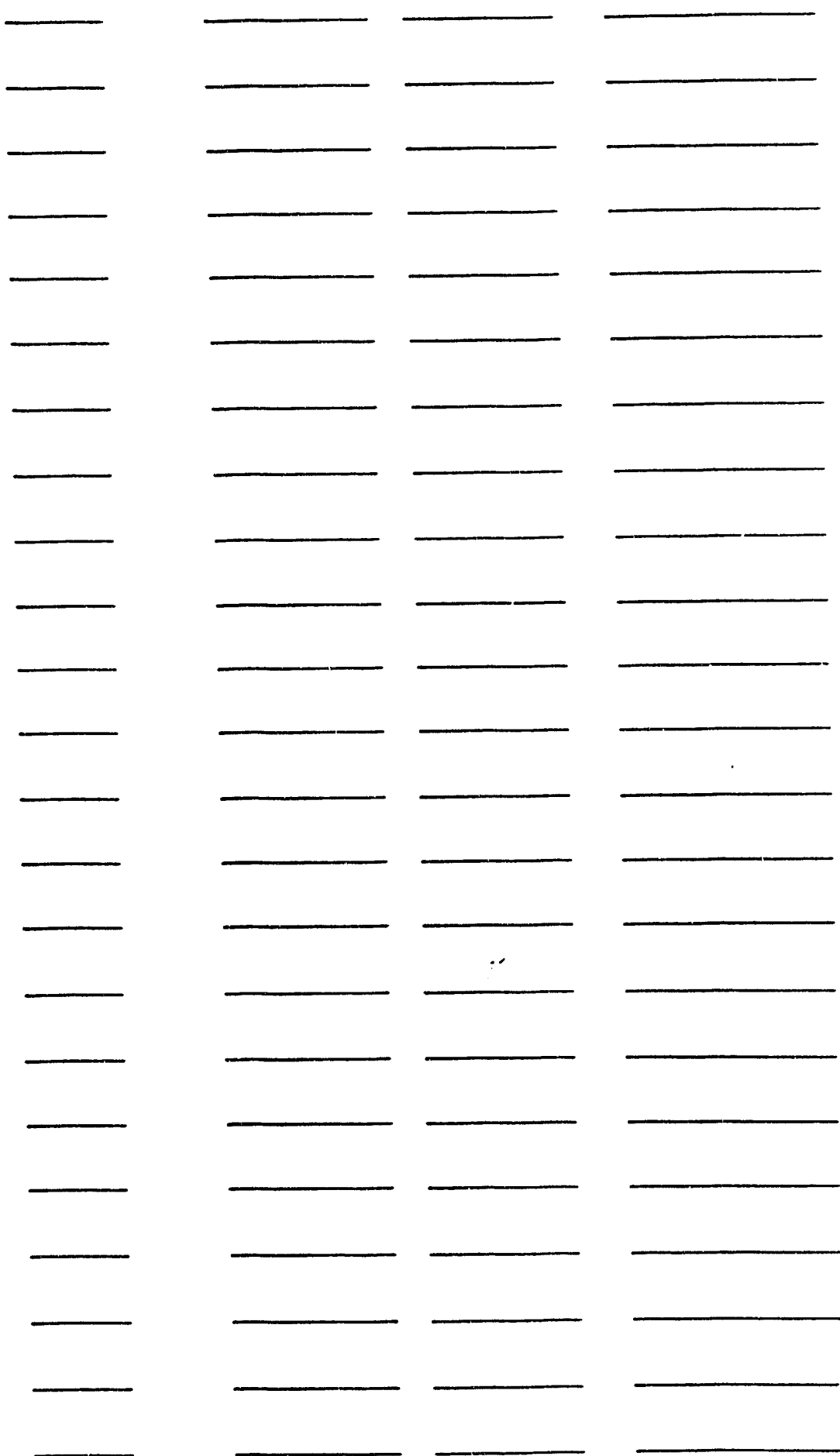

\section{A. 4}


PX

\section{QCCUPANCY}

Changes In occupancy durling the PAST 12 monthe:

Changes in occupancy ant Iclpated in the NEXT 12 months:

\begin{tabular}{|c|c|c|c|c|c|c|}
\hline dae crour & $\begin{array}{c}\text { Number } \\
M \angle \mathbf{E}\end{array}$ & Euld $x \ln e$ & Rert $\operatorname{IIm} \theta$ & Weokende & summer & other \\
\hline $0-5$ yearo & & & & & & \\
\hline $6-17$ & & & & & & \\
\hline $18-64$ & & & & & & \\
\hline $65+$ & & & & & & \\
\hline
\end{tabular}

\section{QRIGINAL SHOWERHEAD EFFICIENCY}

From the homeownera knowledge, wae the orlglnal ohowerhead energy efflclent? (Correlate to bliowere llated on page 3 )

Shower 1
shower 2
shower 3

COMMENTS 
APPENDIX B

SHOWERHEAD INSTALLATION CHECKLIST 


\section{SHOHERHEAD INSTALLATION CHECKLIST}

1. Installation report form completed

2. Characteristics (Chrono) redlined

3. Resident approves of showerhead installation

4. Release form signed

5. $\$ 40$ dispersed to resident/owner

6. Certificate of participation dispersed to resident

7. Showerheads tagged and removed from home

Signed

Installer

Date

B.1 


\section{APPENDIX C}

\section{PARTICIPATION AGREEMENT AND CERTIFICATE OF PARTICIPATION}




\section{: Battelle}

Pacilic Northwest Laboratories Barlelle Boulevard

PO Box 999

Richland. Washinglon 99352

Telephone (509)

\section{ENERGY EFFICIENT SHOWERHEAD PROGRAM}

DI

PX

Installer

Date

Site address:

This is to certify that I am the owner of the property identified above in which new energy efficlent showerheads have been installed in conjunction with the Regional End-Use Metering Program (REMP). I further certify that I am satisfied with the manner in which the showerheads were installed. I have received the sum of $\$ 40.00$ from the above installer, and agree to the release of my old showerheads. I am free to request my old showerheads back within one year of today's date.

Date 


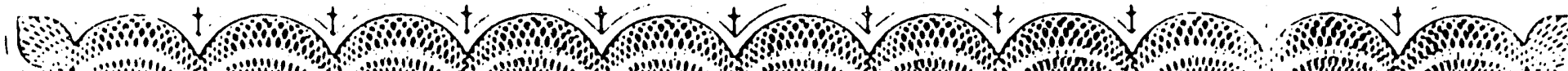

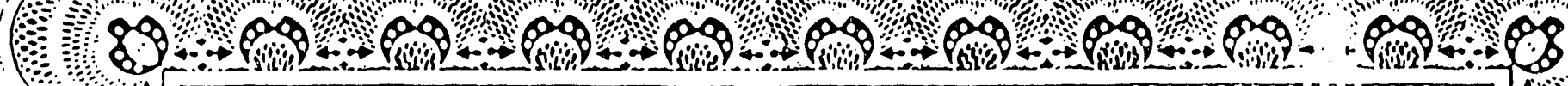

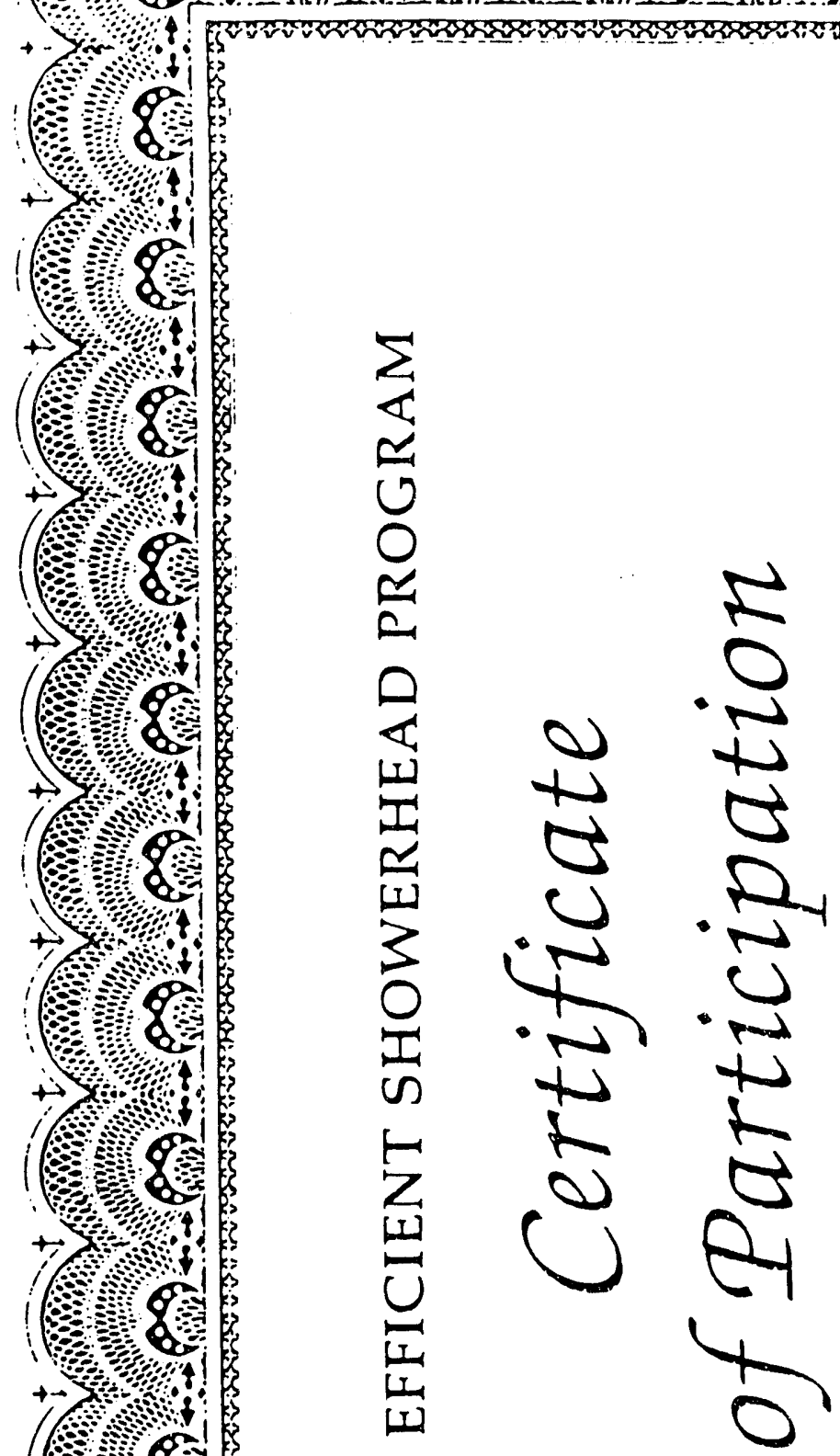

(r)

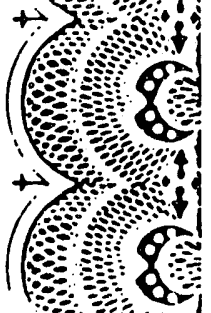

$+7$
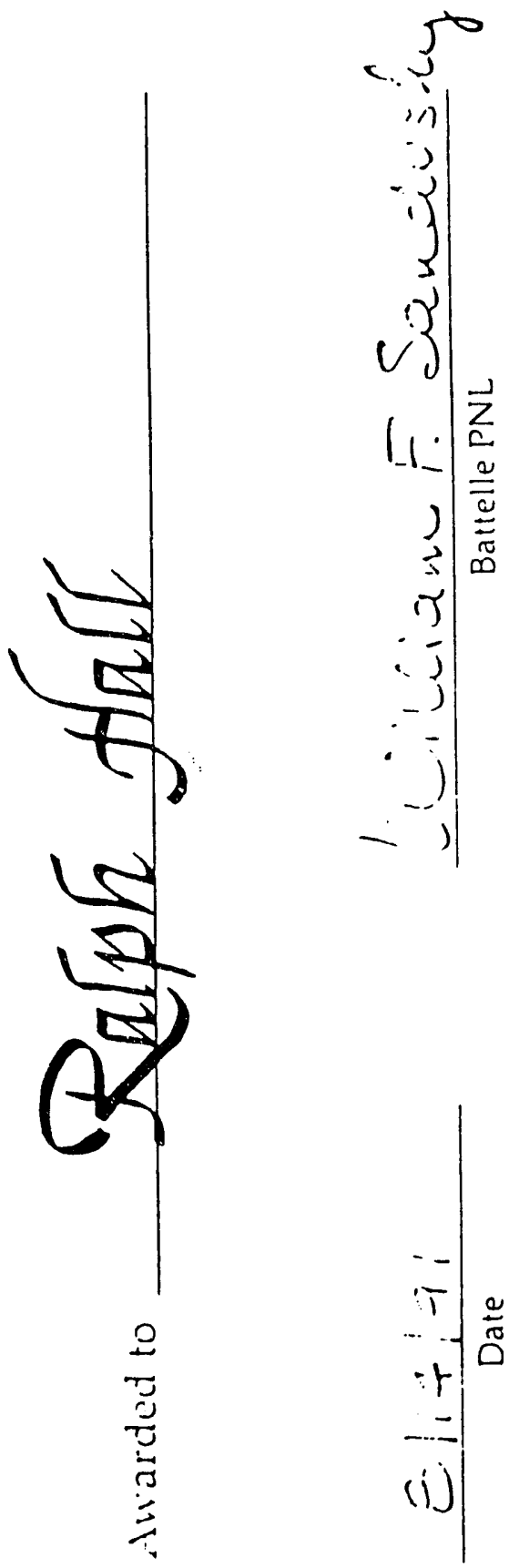

오

ग
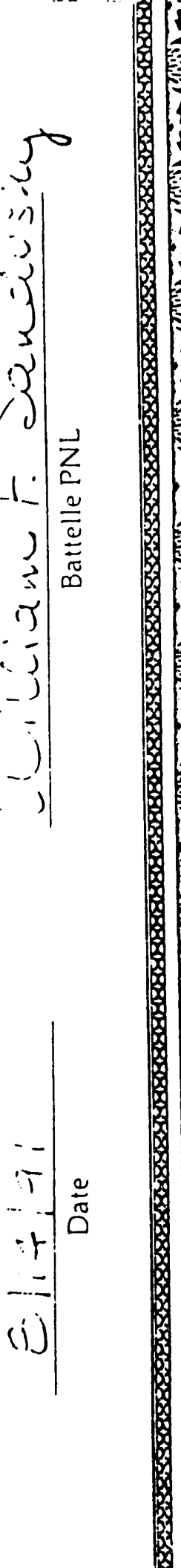
APPENDIX D

IELEPHONE SURVEY 
DI Number

REMP Showerhead 6-Month Progress Phone Survey.

Site Number

PX Number

Date called

Time Called

1. Opening introduction - Annet has her own for REMP participants.

2. On installed (date) our sub-contractor, Pacific Science and Technology, home. (number) low-flow energy-efficient showerhead(s) in your

3a. On a scale from 1 to 10 , where 1 is "not at all satisfied" and 10 is "very satisfied", how satisfied are you overall with the showerhead(s)?

$$
\begin{array}{llllllllll}
1 & 2 & 3 & 4 & 5 & 6 & 7 & 8 & 9 & 10
\end{array}
$$

3b. (If not satisfied.) - Did you replace it (any) with a different one (ones)?

$$
\text { No Yes Don't Know }
$$

3c. (If did replace.) Why was it (were they) replaced?

4. Using the same scale (from 1 to 10 ), how satisfied are you with the volume of water from the showerhead(s)?

$$
\begin{array}{lllllllll}
2 & 3 & 4 & 5 & 6 & 7 & 8 & 9 & 10
\end{array}
$$

5. Using the same scale (from 1 to 10), how satisfied are you with the force of water from the showerhead(s)?

$$
\begin{array}{llllllllll}
1 & 2 & 3 & 4 & 5 & 6 & 7 & 8 & 9 & 10
\end{array}
$$

6. Using the same scale (from 1 to 10 ), how satisfied are you with the sounds from the showerhead(s)?

$$
\begin{array}{lllllllllll}
1 & 2 & 3 & 4 & 5 & 6 & 7 & 8 & 9 & 10
\end{array}
$$

7. Using the same scale (from 1 to 10 ), how satisfied are you with the appearance of the showerhead(s)?

$\begin{array}{llllllllll}1 & 2 & 3 & 4 & 5 & 6 & 7 & 8 & 9 & 10\end{array}$


DI Number

8a. The showerhead has a small valve to reduce the flow. Do you use that valve to control the flow?

No

Yes Don't Know

8b. (If yes to 8a.) How many times per week do you use the valve?

9. How much money do you think the showerhead(s) have saved you in water costs each month? S

10. How much money do you think the showerhead(s) have saved you in electricity costs each month? \$

11. Have you changed your water heater since the showerhead(s) was (were) installation?

No Yes Don't Know

12a. If you have a couple of minutes, I'd like to ask you some questions about how you and your family use water in your home.

In order to get an extimate as to how much hot water you use, could you tell me about how many showers are taken per day and approximately how long they last.

Showers

Baths
Duration

Approximate Gallons

12b. Do you think anyone has changed the frequency or duration of showers or baths since the showerhead(s) was (were) installed?

$$
\text { No Yes Don't Know }
$$

Shower

Duration

13. Has the number of persons living in your household changed since the showerhead installation? .

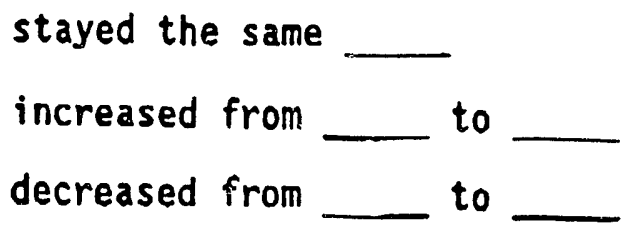

14. How many loads of dishes per week are washed in your household? loads of dishes washed per week 
DI Number

$$
\text { Don't know }
$$

15. How many loads of clothes per week are washed in you household? (Include only those loads washed by the automatic clothes washer.)

loads washed per week
loads washed per week washed in cold water
loads washed per week rinsed in cold water
don't know

16. On the average, how many times do you run out of hot water?

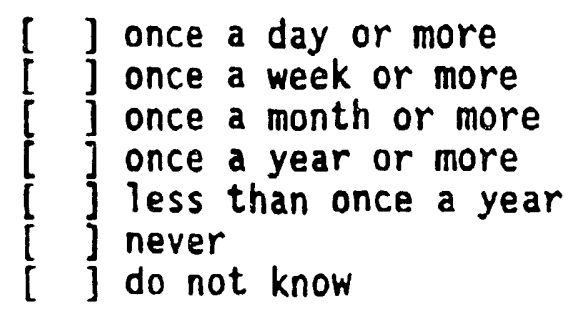

17. Do you use city water or do you have a well? well city

18. We appreciate your input on the energy efficient showerheads. Do you have any comments you would like to make or any questions about the study?

Thank you for your cooperation. 


\section{DISTRIBUTION}

No. of

Cooies

\section{OFFSITE}

12 DOE/Office of Scientific and Technical Coimunication

50 Curtis Hickman

Bonneville Power Administration

P.0. BoX 3621 - RPEB

Portland, OR 97208

\section{Pam Brandis}

Bonneville Power Administration

P.0. Box 3621 - RPEB

Portland, OR 97208

M. L. Carr

Public Power Council

500 NE Multnomah, Suite 729

Portland, OR 97232

\section{ONSITE}

DOE Richland field office

D. R. Segna

\section{Pacific Northwest Laboratory}

S. A. Bailey

T. L. Gilbride

B. L. Mohler

H. M. Warwick (5)

Publishing Coordination

Technical Report Files (5) 

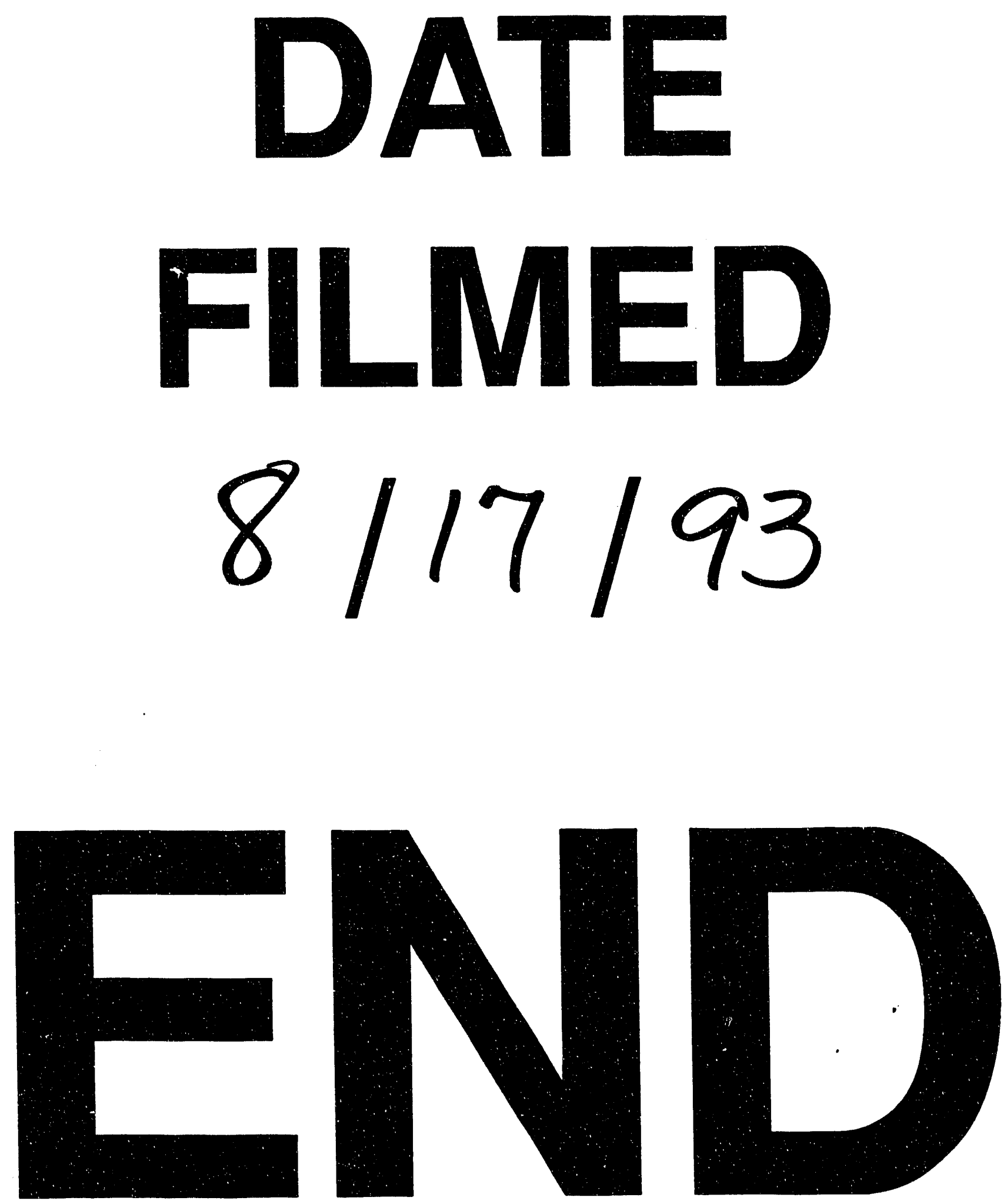

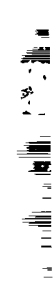


